Article

\title{
Spiro[pyrrolidine-3,3'-oxindoles] and Their Indoline Analogues as New 5-HT6 Receptor Chemotypes
}

\author{
Ádám A. Kelemen ${ }^{1}$, Grzegorz Satala ${ }^{2}$, Andrzej J. Bojarski ${ }^{2}$ and György M. Keserú ${ }^{1, *}$ \\ 1 Medicinal Chemistry Research Group, Research Centre for Natural Sciences, Hungarian Academy of \\ Sciences, Magyar tudósok körútja 2, H1117 Budapest, Hungary; kelemen.adam@ttk.mta.hu \\ 2 Department of Medicinal Chemistry, Institute of Pharmacology, Polish Academy of Sciences, \\ 12 Smętna Street, 31-343 Krakow, Poland; grzegorz.satala@gmail.com (G.S.); \\ andrzej.bojarski@gmail.com (A.J.B.) \\ * Correspondence: keseru.gyorgy@ttk.mta.hu or gy.keseru@ttk.mta.hu; Tel.: +36-1-382-6821
}

Received: 1 November 2017; Accepted: 12 December 2017; Published: 14 December 2017

\begin{abstract}
Synthetic derivatives of spiro[pyrrolidinyl-3,3'-oxindole] alkaloids (coerulescine analogues) were investigated as new ligands for aminergic G-protein coupled receptors (GPCRs). The chemical starting point 2'-phenylspiro[indoline-3,3'-pyrrolidin]-2-one scaffold was identified by virtual fragment screening utilizing ligand- and structure based methods. As a part of the hit-to-lead optimization a structure-activity relationship analysis was performed to explore the differently substituted 2'-phenyl-derivatives, introducing the phenylsulphonyl pharmacophore and examining the corresponding reduced spiro[pyrrolidine-3,3'-indoline] scaffold. The optimization process led to ligands with submicromolar affinities towards the $5-\mathrm{HT}_{6}$ receptor that might serve as viable leads for further optimization.
\end{abstract}

Keywords: oxindole; indoline; coerulescine; 5-HT 6 R; G-protein coupled receptor

\section{Introduction}

The recent isolation of naturally occurring and biologically active spiropyrrolidinyl-oxindole alkaloids initiated a significant research on synthetic derivatives [1], particularly compounds with the spiro[indoline-3,3'-pyrrolidine]-2-one ring system. Spiropyrrolidinyl-oxindole alkaloids were isolated from different species including Gelsemium sempervirens, Aspidosperma, Mitragyna, Ourouparia, Rauwolfia, Vinca species [2]. The most prominent examples are rynchophylline (1), formosanine (2), coerulescine (3), horsfiline (4) and elacomine (5) that show diverse biological activity (Figure 1). Although these compounds have a common tryptamine derived motif, a ChEMBL-analysis [3] revealed that no representatives have been ever tested against serotonergic targets. Developing ligand-(FrAGs) [4] and structure-based (FrACS) [5] methods for the identification of aminergic receptor ligands we identified 6 as a micromolar 5-hydroxytryptamine receptor $6\left(5-\mathrm{HT}_{6} \mathrm{R}\right)$ ligand.

The $5-\mathrm{HT}_{6} \mathrm{R}$ is a member of the Class A G-protein coupled receptors (aminergic family) considered to be a current and promising drug target for the treatment of several central nervous system related indications, such as: cognitive, learning and memory deficits related to Alzheimer's disease [6], Parkinson's disease [7] and schizophrenia [8]. Chemical similarity to the endogenous agonist serotonin explains the most frequent heteroaromatic ring systems routinely used in $5-\mathrm{HT}_{6} \mathrm{R}$ ligands that include indoles, indolines, indazoles, pyrrolo[2,3-b]pyridines, pyrazolo[1,5- $a]$ pyridines, [1,2,3]-triazolo[1,5-a]pyrimidines and further $5+6$ condensed $N$-heterocycles. Pharmacophore based approaches on $5-\mathrm{HT}_{6} \mathrm{R}$ antagonists are typically focused to the canonical pharmacophore model [9] (Figure 2), which is defined as having two hydrophobic rings/ring systems connected by a hydrogen bond acceptor (e.g., sulfonyl, sulfonamide linker). Optionally, a positively ionizable residue is included in one of the hydrophobic sites of the ligands, typically offering an interacting moiety with the $\mathrm{D}^{3.32}$ 
aspartate residue of aminergic GPCR's as a key factor of aminergic 7TM-receptor activation [10]. A further pharmacophore feature might contain an additional intramolecular hydrogen bond donor moiety further stabilizing the binding conformation of the ligands [11] (see Figure 2). Selectivity among other aminergic GPCR's was shown [12] to be accessible through omitting the positively ionizable group in the $5-\mathrm{HT}_{6} \mathrm{R}$ antagonists. Bis(hetero)arylsulphonyl- and sulfonamide substituents also contribute to $5-\mathrm{HT}_{6} \mathrm{R}$ affinity and selectivity.

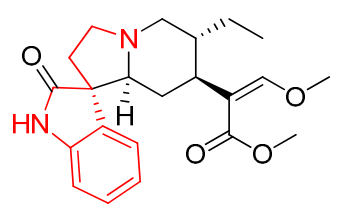

rychnophylline

1<smiles>COc1ccc2c(c1)[C@]1(CCN(C)C1)C(=O)N2</smiles>

(-)-horsfiline

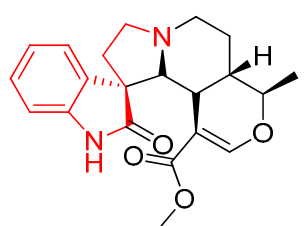

formosanine

2<smiles>CC(C)C1NCCC12C(=O)Nc1cc(O)ccc12</smiles>

$(+)$-elacomine

5

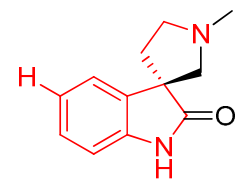

$(-)$-coerulescine

3

Figure 1. Representative natural spiropyrrolidinyl-oxindole alkaloids. The tryptamine scaffold is shown as red skeleton.

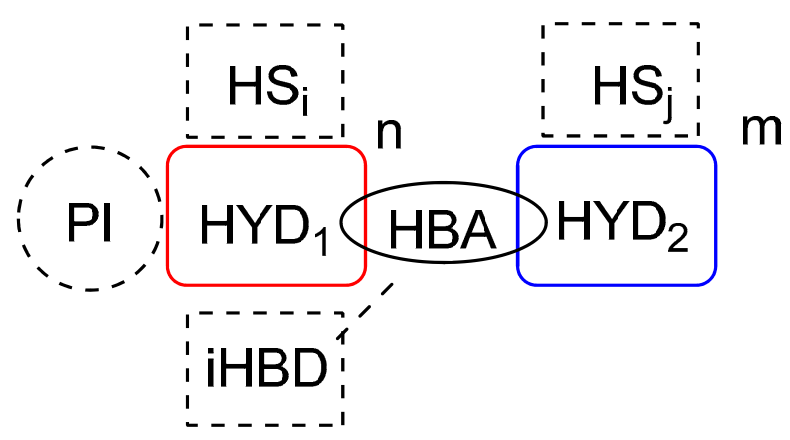

Figure 2. General pharmacophore model of $5-\mathrm{HT}_{6} \mathrm{R}$ antagonists. PI: positive ionisable portion; $\mathrm{HYD}_{1,2}$ : hydrophobic sites; iHBD: intramolecular hydrogen bond donor site; HBA: hydrogen bond acceptor feature; $\mathrm{HS}_{\mathrm{i}, \mathrm{j}}$ : substituents on the hydrophobic sites.

The tryptamine derived scaffold of 6 and its alignment with the published $5-\mathrm{HT}_{6} \mathrm{R}$ pharmacophore [9] prompted us to explore the structure-activity relationship around the spiropyrrolidinyl-oxindole core. Here we report the results of our hit-to-lead program, which led to an identification of promising $5-\mathrm{HT}_{6} \mathrm{R}$ ligands of this chemotype.

\section{Results and Discussion}

\subsection{Identification and Early Structure-Activity Data on Spiro[pyrrolidine-3,3'-oxindole] Derivatives}

Fragment libraries containing a couple hundreds or even thousands of small polar molecules are routinely used for hit identification at the early stage of drug discovery. Fragment screening provides diverse chemotypes and significant operational freedom for the further optimization of promising hits. Inspired by these advantages in a recent study we developed a strategy for aminergic focused fragment libraries using a sequential filtering methodology applying ligand- 
and structure-based scoring functions $[4,5]$. The prospective validation was performed on our in-house library of 1183 fragments. A physicochemical-property based scoring, followed by docking the fragments into an ensemble of carefully selected aminergic GPCR X-ray structures (PDB ID: 3PBL, 3RZE, 4IB4, 4IAQ, 3UON, 4MQT, 4LDE, 2RH1, 3NY9). This resulted in a set of 36 top ranked hit molecules which were measured on an aminergic target not being included in the original docking ensemble, namely $5-\mathrm{HT}_{6} \mathrm{R}$. We demonstrate the usefulness of the method for comprehensive aminergic focused screenings. Out of the four hits with low micromolar inhibitory results, the structurally novel 2'-(3-fluorophenyl)spiro[indoline-3,3'-pyrrolidin]-2-one (6) possessing the spiro[pyrrolidine-3,3'-oxindole] scaffold (Table 1), was selected for further optimization.

Table 1. Serotonergic G-protein coupled receptor (GPCR) panel of $\mathbf{6}$ as measured in binding assays of four serotonin receptors $\left(K_{\mathrm{i}}\right.$ values are in $\left.\mu \mathrm{M}\right)$.

\begin{tabular}{llllll}
\hline ID & 5-HT & & & \\
\hline
\end{tabular}

As the next step of exploring the structure-activity relationship substructure search in the MCULE purchasable database [13] of 5 million compounds resulted in further 887 spiro[pyrrolidine-3,3'-oxindole] derivatives. The molecules were prepared by Schrödinger's LigPrep [14] creating possible conformers, tautomers and protonation states by default settings. The ligands were then projected to single precision molecular docking analysis on a nine membered ensemble of molecular dynamics frames of an $5-\mathrm{HT}_{6} \mathrm{R}$ homology model [15] (built using $5-\mathrm{HT}_{2 \mathrm{~B}} \mathrm{R}$ X-ray crystal structure [16] in complex with ergotamine as template (PDB ID: 4IB4)). The docking poses were filtered in a post-processing step keeping only binding modes forming hydrogen bonds towards Asp $106^{3.32}$, Asn288 8.55 and optionally Ser193 ${ }^{5.43}$, occupying a primary hydrophobic cleft defined by Trp $281^{6.48}$, Phe $284^{6.51}$ and Phe $285^{6.52}$. A secondary hydrophobic subpocket was defined

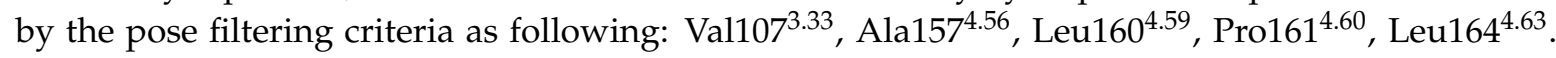
The satisfactory poses of the molecules were scored to have the best ranking in possibly all of the 9 frames using consensus ranking [5]. Altogether ten compounds (7-16) were purchased and tested in our serotonergic panel (Table 2).

In spite of the structural diversity, all virtual screening hits were lacking substitution at the oxindole scaffold. However, compounds 7, 9 and $\mathbf{1 0}$ having oxygen-containing substituents in the 3,4-positions of the 2'-phenyl ring showed somewhat improved affinity compared to the initial compound 6 . The moderate improvement in affinity and the lack of selectivity amongst the closely related serotonergic targets have driven us to interpret the results in the context of the known $5-\mathrm{HT}_{6} \mathrm{R}$ pharmacophore patterns [17] (Figure 3). This analysis suggests that introducing a phenylsulfonyl moiety either to the 1-nitrogen at the oxindole ring or to the $1^{\prime}$-nitrogen at the pyrrolidine ring would be beneficial for both the affinity and selectivity of this chemotype. 
Table 2. Serotonergic GPCR panel of derivatives substituted in the $2^{\prime}$-phenyl moiety as measured in binding assays of four serotonin receptors $\left(K_{\mathrm{i}}\right.$ values are in $\left.\mu \mathrm{M}\right)$.

\begin{tabular}{|c|c|c|c|c|c|}
\hline ID & Structure & $5-\mathrm{HT}_{1 \mathrm{~A}}$ & $5-\mathrm{HT}_{2 \mathrm{~A}}$ & $5-\mathrm{HT}_{6}$ & $5-\mathrm{HT}_{7}$ \\
\hline 7 & & 7.07 & 5.45 & 2.26 & 2.69 \\
\hline 8 & & 1.74 & 2.28 & 3.18 & 1.09 \\
\hline 9 & & 9.84 & 2.69 & 3.20 & 8.82 \\
\hline 10 & & 12.08 & 4.33 & 4.11 & 12.74 \\
\hline 11 & & 49.11 & 8.68 & 6.20 & 58.96 \\
\hline 12 & & 45.67 & 1.12 & 6.63 & 10.45 \\
\hline 13 & & 7.14 & 5.77 & 7.73 & 7.49 \\
\hline 14 & & 7.76 & 4.54 & 8.62 & 8.98 \\
\hline 15 & & 40.50 & 23.70 & 9.49 & 46.72 \\
\hline 16 & & not active & 53.89 & 16.54 & not active \\
\hline
\end{tabular}




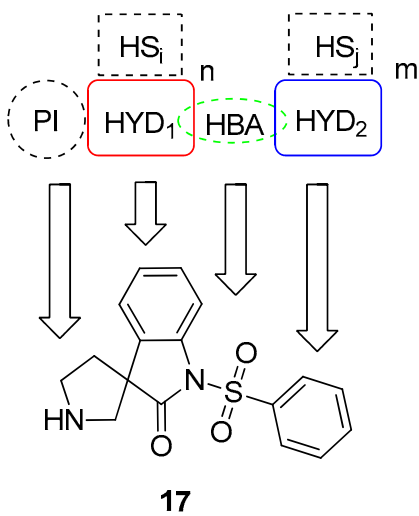

(a)

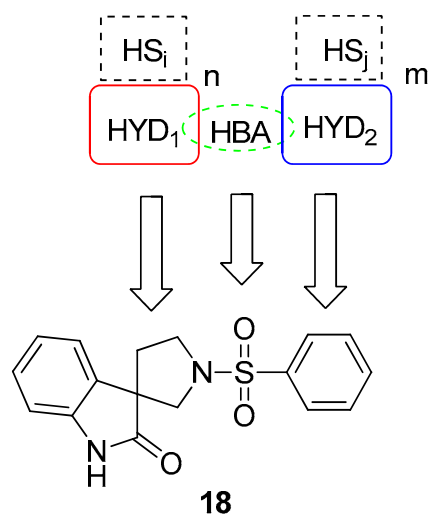

(b)

Figure 3. (a) 1-(phenylsulfonyl)spiro[indoline-3,3'-pyrrolidin]-2-one (17) superimposed onto the classical pharmacophore; (b) 1'-(phenylsulfonyl)spiro[indoline-3,3'-pyrrolidin]-2-one (18) fitting to the pharmacophore pattern lacking a positive ionisable moiety.

\subsection{Hit-to-Lead Optimization of Spiro[pyrrolidine-3,3'-oxindoles]}

Detailed elaboration of the spiro[pyrrolidine-3,3'-oxindole] scaffold required a viable synthesis strategy for the preparation of designed analogues. The first, conventional approach is based on an intramolecular Mannich-reaction used in case of several alkaloids including ( \pm )-horsfiline (4) [18] and Spirotryprostatin B [19]. An alternative approach is the oxidative reaction of tryptolines induced by tert-butyl hypochlorite, $\mathrm{N}$-bromosuccinimide, $\mathrm{N}$-chlorosuccinimide, sodium tungstate, lead tetraacetate, or osmium tetroxide $[20,21]$. The reaction is completed by the subsequent elimination of water that finally results in the reorganization of the ring system to spiro[pyrrolidine-3,3'-oxindoles] (Scheme 1).

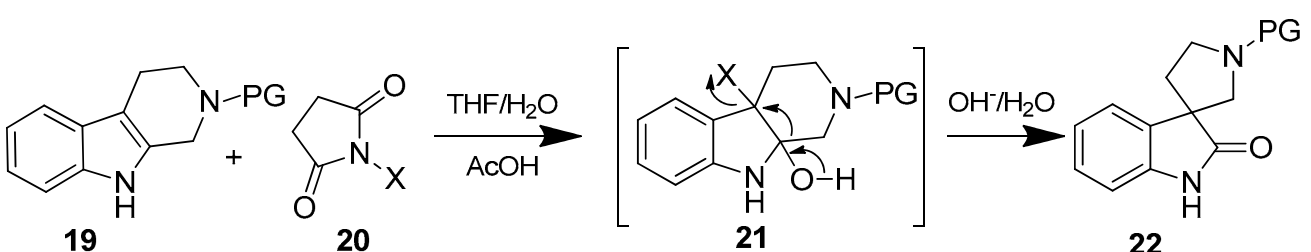

PG: protecting group, e.g. tert-butyloxycarbonyl (Boc), benzyl (Bn), benzyloxy carbamate (Cbz), etc. $\mathrm{X}: \mathrm{Cl}, \mathrm{Br}$

Scheme 1. Mechanism of the succinimide assisted oxidative spiro-rearrangement of tryptolines.

Further, sophisticated approaches such as [1,3]-dipolar cycloaddition reactions of azomethine ylides [22], radical cyclization by AIBN [23], intramolecular Heck reaction [24] and asymmetric nitroolefination of oxindoles [25] are also available, however, used less frequently.

For the effective exploration of the structure-activity relationship we need a feasible and universal approach with acceptable functional group tolerance and high variability around the spiro-oxindole core. Considering the requirements of the early stage optimization program we aimed a synthesis strategy that

- uses readily accessible, simple starting materials

- applies well-documented, readily available reagents

- has key intermediates to access a wide variety of derivatives

- is not necessarily stereoselective at this stage of the optimization 
The oxidative spiro-rearrangement reactions offer a wide variety of oxidative reagents [20,21,26-33] and the corresponding starting materials are readily accessible through Pictet-Spengler reaction of tryptamines [34] (Scheme 2).

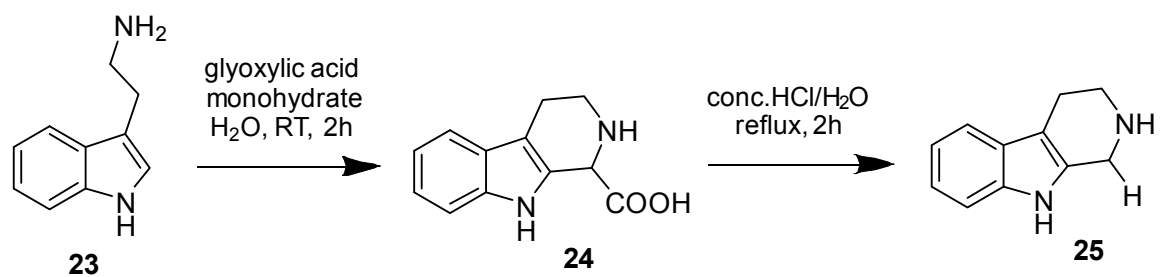

Scheme 2. Synthesis of tryptoline by Pictet-Spengler condensation.

Following this synthesis strategy, tryptamine (23) was used as a starting material for the synthesis of the common intermediate tryptoline (25). The Pictet-Spengler condensation reaction was performed by glyoxylic acid-monohydrate in aqueous medium [35]. The crude acid intermediate $\mathbf{2 4}$ was decarboxylated in refluxing concentrated hydrochloric acid affording the tetrahydro- $\beta$-carboline. The first synthetic route depicted in Scheme 3 starts with the N-acylation of the tryptoline (25). The application of $\mathrm{Cbz}$ (carboxybenzyl) [36] protecting group was necessary for two reasons: 1. achieve the sulfonylation at the oxindol-nitrogen, 2 . the spiro-rearrangement reaction is not occurring in case of unsubstituted pyrido-nitrogen. $N$-chlorosuccinimide [37] was used in the first experiments as halogenating reagent, providing the Cbz-protected spiro[pyrrolidine-3,3'-oxindole]. The phenylsulfonylation was performed either by using lithium-hexamethyl disilazane [38] and sodium hydride [39] as deprotonating agents and acid scavengers. Finally, the deprotection of the Cbz-group by hydrogenation [40] resulted in the desired 1-(phenylsulfonyl)spiro[indoline-3,3'-pyrrolidin]-2-one (17) compound. Following an alternative way, the more basic pyrido-nitrogen of tryptoline $29 \mathrm{might}$ be first sulfonylated [41] followed by the $N$-bromosuccinimide assisted spiro-cyclization to 18 [42].

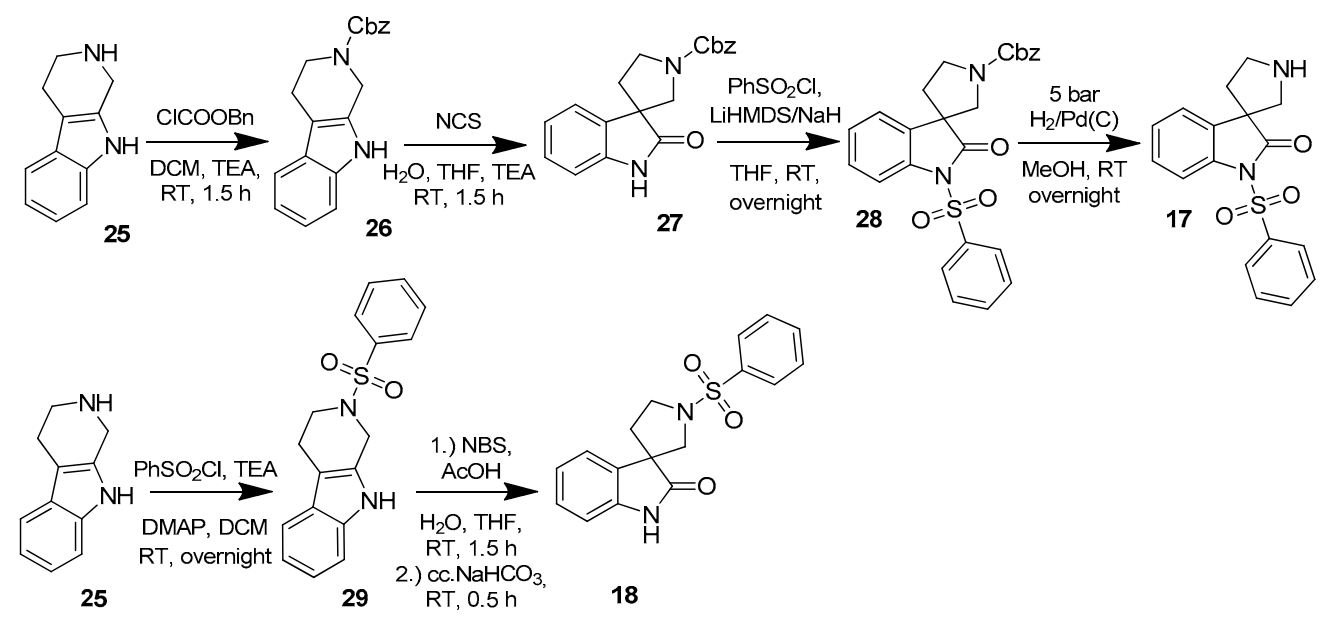

Scheme 3. Synthesis of 1- and 1'-phenylsulfonyl derivatives.

Compounds $\mathbf{1 7}$ and $\mathbf{1 8}$ showed improved selectivity towards the $5-\mathrm{HT}_{6} \mathrm{R}$ (Table 3 ) as compared to the non-sulfonylated 2'-phenyl derivatives, investigated in the first batch (compounds 15-24), however, no improvement in the binding affinity was detected. 
Table 3. Serotonergic GPCR panel of the $N$-phenylsulfonylated derivatives at $\mathrm{N}^{\prime}$ and $\mathrm{N}$-positions as measured in binding assays of four serotonin receptors $\left(K_{\mathrm{i}}\right.$ values are in $\left.\mu \mathrm{M}\right)$.

\begin{tabular}{|c|c|c|c|c|c|}
\hline ID & Structure & $5-\mathrm{HT}_{1 \mathrm{~A}}$ & $5-\mathrm{HT}_{2 \mathrm{~A}}$ & $5-\mathrm{HT}_{6}$ & $5-\mathrm{HT}_{7}$ \\
\hline 17 & & not active & not active & 12.30 & 58.31 \\
\hline 18 & & not measured & 87.35 & 6.86 & not active \\
\hline
\end{tabular}

Facilitating the potency optimization, we followed the classical $5-\mathrm{HT}_{6} \mathrm{R}$ pharmacophore pattern and tried to remove the polar interacting hydrogen bond acceptor feature in the oxindole ring of 17. For better understanding of the indole, indoline and oxindole-related chemical space of known $5-\mathrm{HT}_{6} \mathrm{R}$ ligands we collected all compounds, with at least $0.1 \mu \mathrm{M}$ activity towards h5- $\mathrm{HT}_{6} \mathrm{R}$ from the ChEMBL database.

Substructure filtering by the query of $\mathbf{3 0}$ (Figure 4) revealed that altogether 3 examples were found for oxindoles, as $5-\mathrm{HT}_{6} \mathrm{R}$ ligands. All hits belong to the $3^{\prime}$-phenylspiro[indoline-3,2'-thiazolidine]-2, $4^{\prime}$-dione scaffold 31 that was identified by Hostetler et al. [43]. Searching for the 1-(phenylsulfonyl) indoline scaffold 32, 27 actives were found with the structure 33 . Out of the 27 active molecules 4 possess a positive ionizable moiety built upon the phenyl side of the sulfonyl and all of the remaining examples are equipped by the classical tryptamine-type amine feature. Searching by the 1-(phenylsulfonyl)indole 34 query resulted in 397 examples with the structure 35 . The structures were analyzed based on the chain-length distance between the 3-carbon of the indole ring and the positive ionizable basic nitrogen atom, if any. We found 20 examples representing indoles with attached basic nitrogen (all tertiary amines). Only five compounds were identified with a single methylene linker out of which 2 were primary amines and 3 were tertiary amines. The largest part of the with structure 34 contains ethylene linker (201 examples out of 397) of which 123 were tertiary amines, 51 were secondary amines and 19 were primary amines. Much less compounds have 3 atom long linkage, 54 examples were identified, with 21 tertiary amines and 33 secondary amines and no primary amines. No ligands were found with basic nitrogen's being further than 3 atoms from the indole core.

To conclude, we have aimed to synthesize different 1-(phenylsulfonyl)indolines (scaffold 32), being substituted in the 1'-pyrrolidine nitrogen with either basic-nitrogen containing, or lipophilic groups, presented in Scheme 4-compounds 39a-b. Based on these considerations, first we benzylated [44] the tryptoline (25) to afford 36a, further converting it to the corresponding spiro-derivative [45] 37a. The reduction of the oxindole oxo-group was performed by applying borane-tetrahydrofuran complex in refluxing absolutized tetrahydrofuran [46]. It was an important observation, that the reduction step has to precede the sulfonylation, to avoid the formation of side products when treating the sulfonamide with the boronic reagent. The phenyl-sulfonylated product 39a was afforded either by applying LiHMDS [38] or trietylamine/dimethylaminopyridine [47] reagents. The pyridine-4-ylmethyl derivative (39b) was synthesized based on the same route, however, as a first step, the tryptoline (25) was treated with 4-chloromethylpyridine [48,49]. 


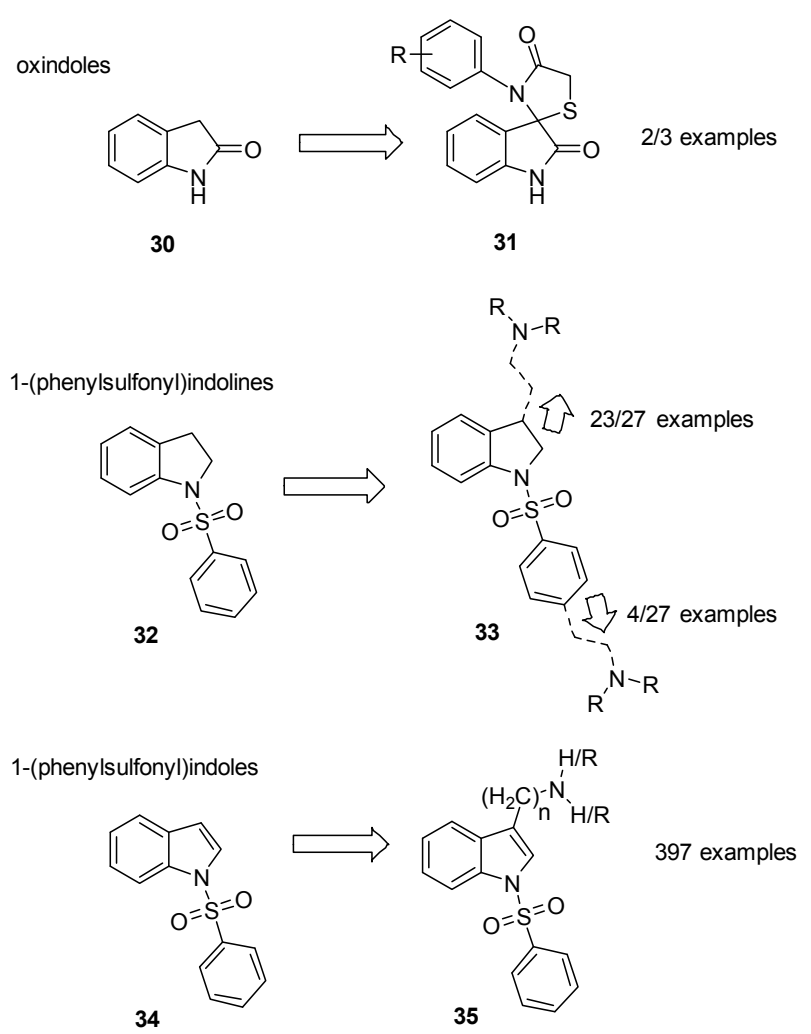

Figure 4. Substructure analysis of ChEMBL 5-HT 6 R active compounds.

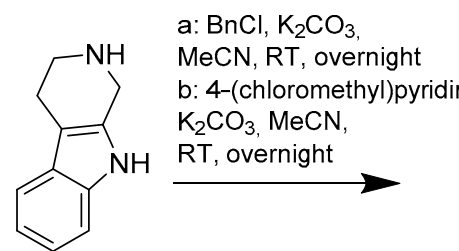

25

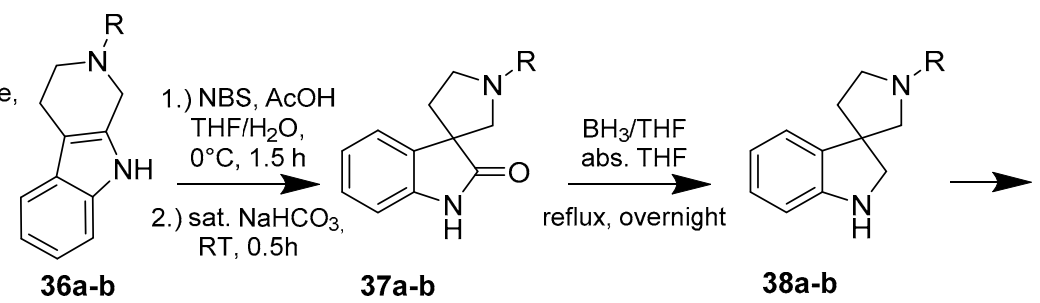

36a-b

37a-b

$38 a-b$

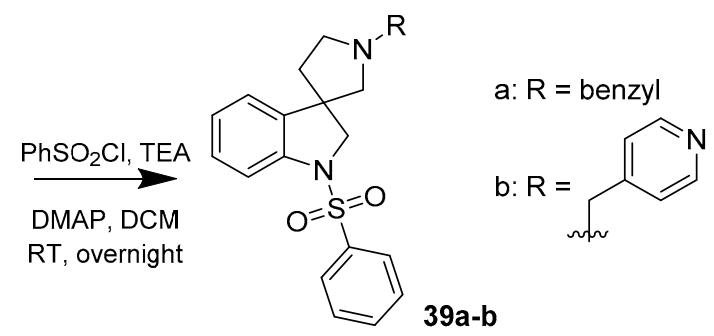

Scheme 4. Synthesis of $\mathrm{N}^{\prime}$-substituted and $N$-phenylsulfonylated indolines.

We also intended to examine the effect of only transforming our initial test compound $\mathbf{1 7}$ to the corresponding reduced indoline, however the debenzylation step of 39a afforded unexpected products (Scheme 5, 40a and 40b). In case, when methanol was applied as solvent for the debenzylation by catalytic hydrogenation, a methylated product 40a has formed and respectively, the use of ethanol afforded an ethyl-alkylated derivative $\mathbf{4 0 b}$. 


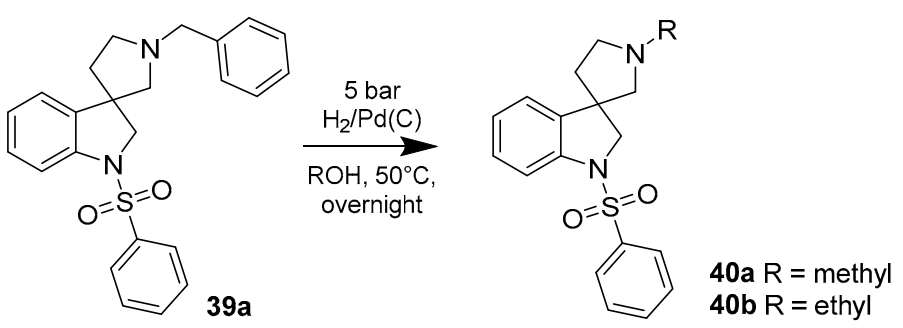

Scheme 5. Synthesis of $N^{\prime}$-methyl and ethyl derivatives.

However, both the alkylated derivatives showed some improvement of binding affinity to reach the low micromolar range, the compound possessing the biggest lipophilic, bulky group 43a has produced the best, submicromolar binding affinity, with both selectivity against the other closely related serotonergic targets (Table 4 ).

Table 4. Serotonergic GPCR panel of $N$-phenylsulfonyl indolines with different $\mathrm{N}^{\prime}$-substituents as measured in binding assays of four serotonin receptors $\left(K_{\mathrm{i}}\right.$ values are in $\left.\mu \mathrm{M}\right)$.

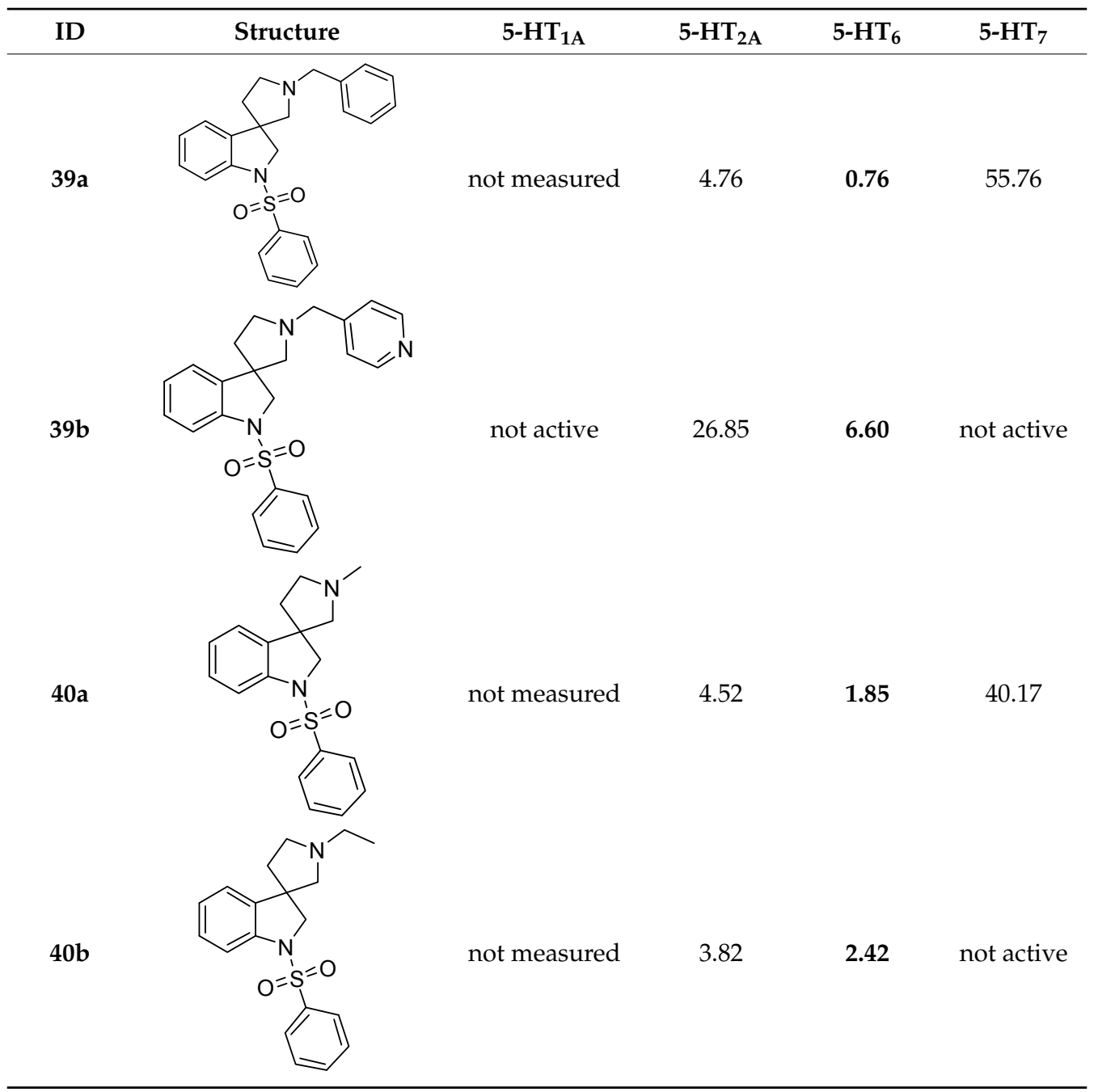

The submicromolar affinity of 39a prompted us investigating the substituent vectors at both the benzylic and the phenylsulfonyl rings by walking fluorine substituents around. This methodology, often referred as fluoro-scan has been used effectively for the identification of sites tolerant to functionalization. In particular, fluoro-scan explores the impact of enhanced lipophilicity, H-bonding 
and/or filling a small pocket [50]. In case of the $N^{\prime}$-benzylic substitution [13] pattern, 2-, 3- and 4-fluorobenzylchlorides were used as alkylating agents in order to synthesize the corresponding fluorinated indolines (Scheme 6, 44a-c).

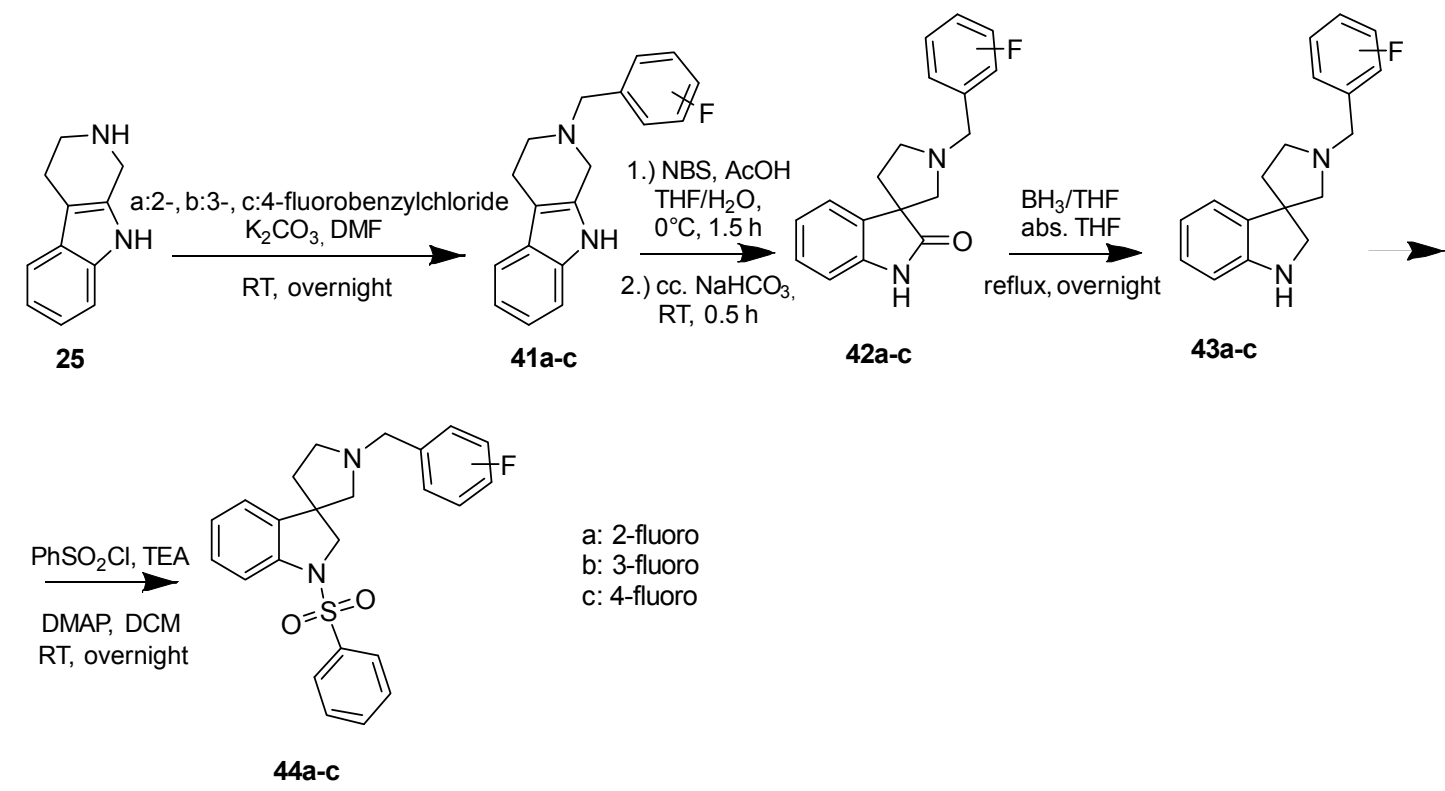

Scheme 6. Fluoro-scan of the $N^{\prime}$-benzyl direction.

The substitution of benzylic ring with fluorine caused a minor decrease in affinity, thus has shown, that growing towards this direction is not beneficial (Table 5). On the other hand, however, some improvement in the selectivity was observed.

Table 5. Serotonergic GPCR panel of the fluorobenzyl derivatives as measured in binding assays of three serotonin receptors $\left(K_{\mathrm{i}}\right.$ values are in $\left.\mu \mathrm{M}\right)$.

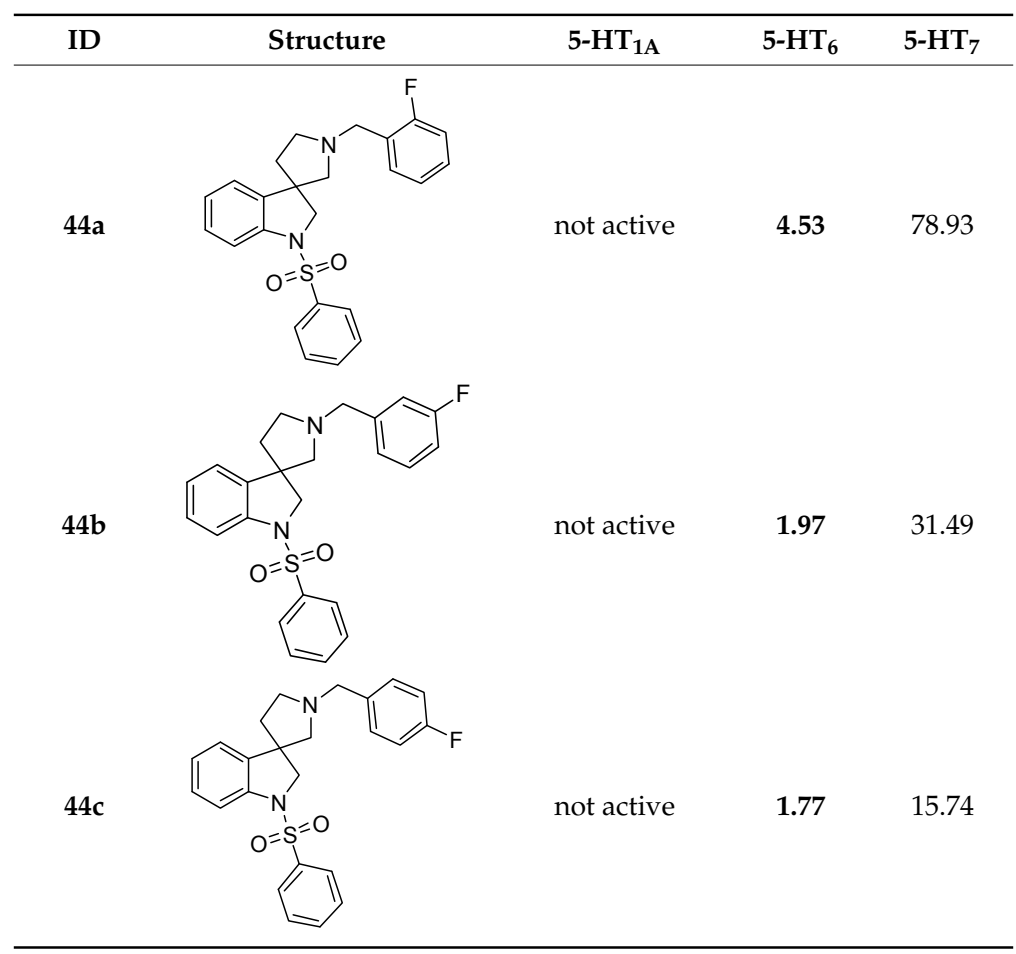


The corresponding fluorophenylsulfonyl derivatives $46 \mathbf{a}-\mathbf{c}$ were synthesized from compound 38a intermediate, previously synthesized (Scheme 7).<smiles>c1ccc(CN2CCC3(CNc4ccccc43)C2)cc1</smiles>

$38 a$<smiles>[R]c1ccc(S(=O)(=O)Cl)cc1</smiles>

45a-c

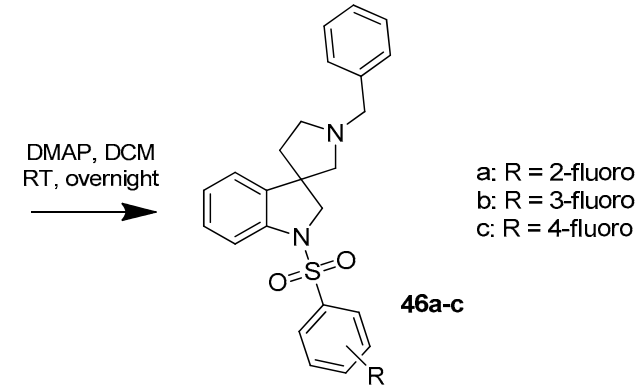

Scheme 7. Fluoro-scan of the $N$-phenylsulfonyl direction.

The alternative growing direction towards the phenylsulfonyl ring (compounds 46a-c) showed improvement in the affinities (see Table 6), compared to the results of 39a, also retaining the good selectivity against the $5-\mathrm{HT}_{7}$ subtype. These data suggest, that position 2 of the phenylsulfonyl group of $46 \mathbf{a}$ is beneficial and therefore it is worth to explore this vector during the forthcoming lead optimization program.

Table 6. Serotonergic GPCR panel of the fluorophenylsulfonyl derivatives as measured in binding assays of three serotonin receptors $\left(K_{\mathrm{i}}\right.$ values are in $\left.\mu \mathrm{M}\right)$.

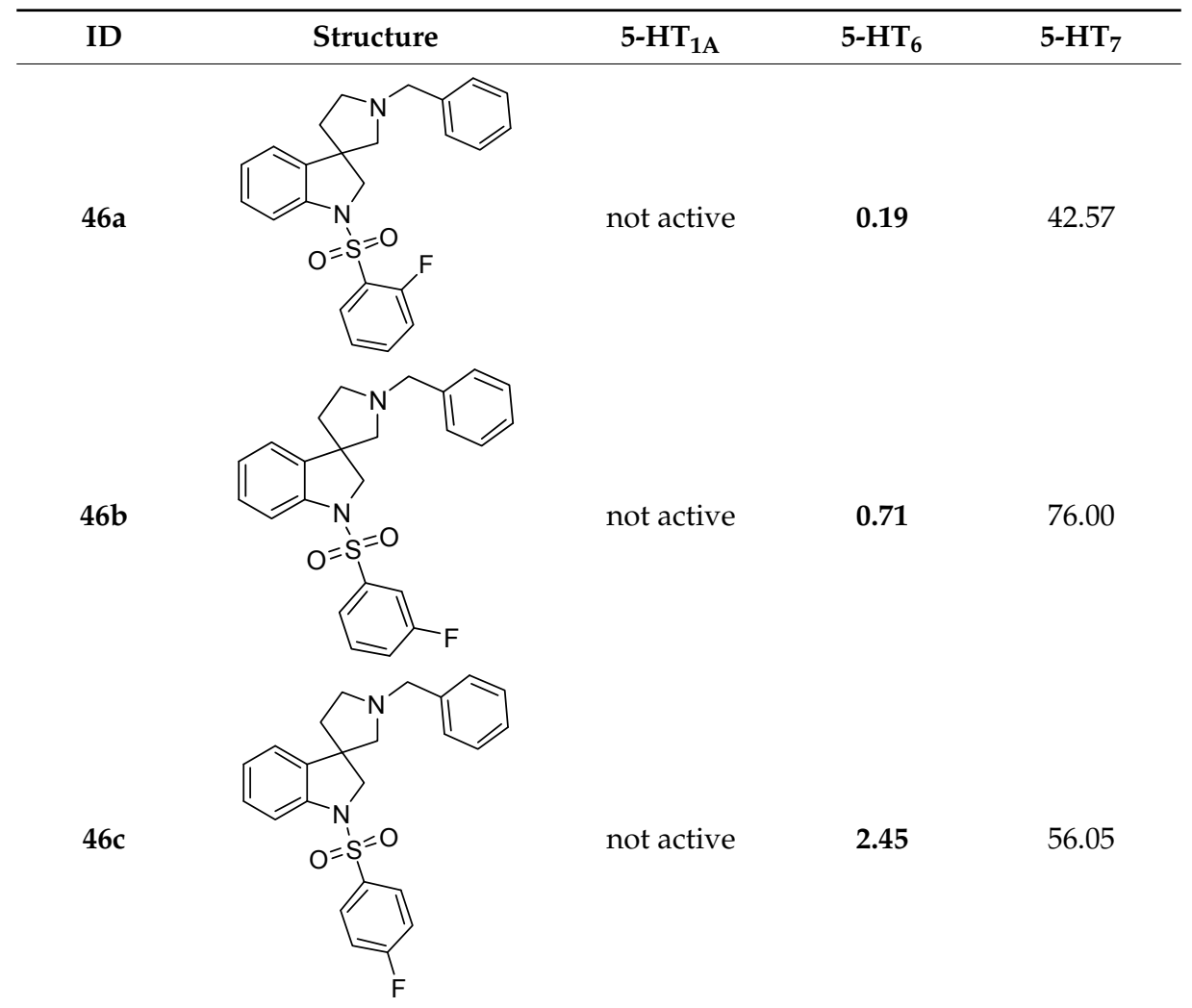

\subsection{Binding Mode Analysis of the Optimized 5-HT 6 R Ligand}

We have performed a docking analysis of the 1'-benzyl-1-((2-fluorophenyl)sulfonyl)-spiro[indoline-3, $3^{\prime}$-pyrrolidine] (46a) 5- $\mathrm{HT}_{6} \mathrm{R}$ antagonist using the receptor model reported earlier [15]. Docking of 46a by Schrödinger-Glide either with, or without applying any constraints (requiring hydrogen bonding 
with both Asn288 $8^{6.55}$ and/or Ser193 $3^{5.43}$ ) resulted in consistent docking poses inside the orthosteric binding pocket (Figure 5).

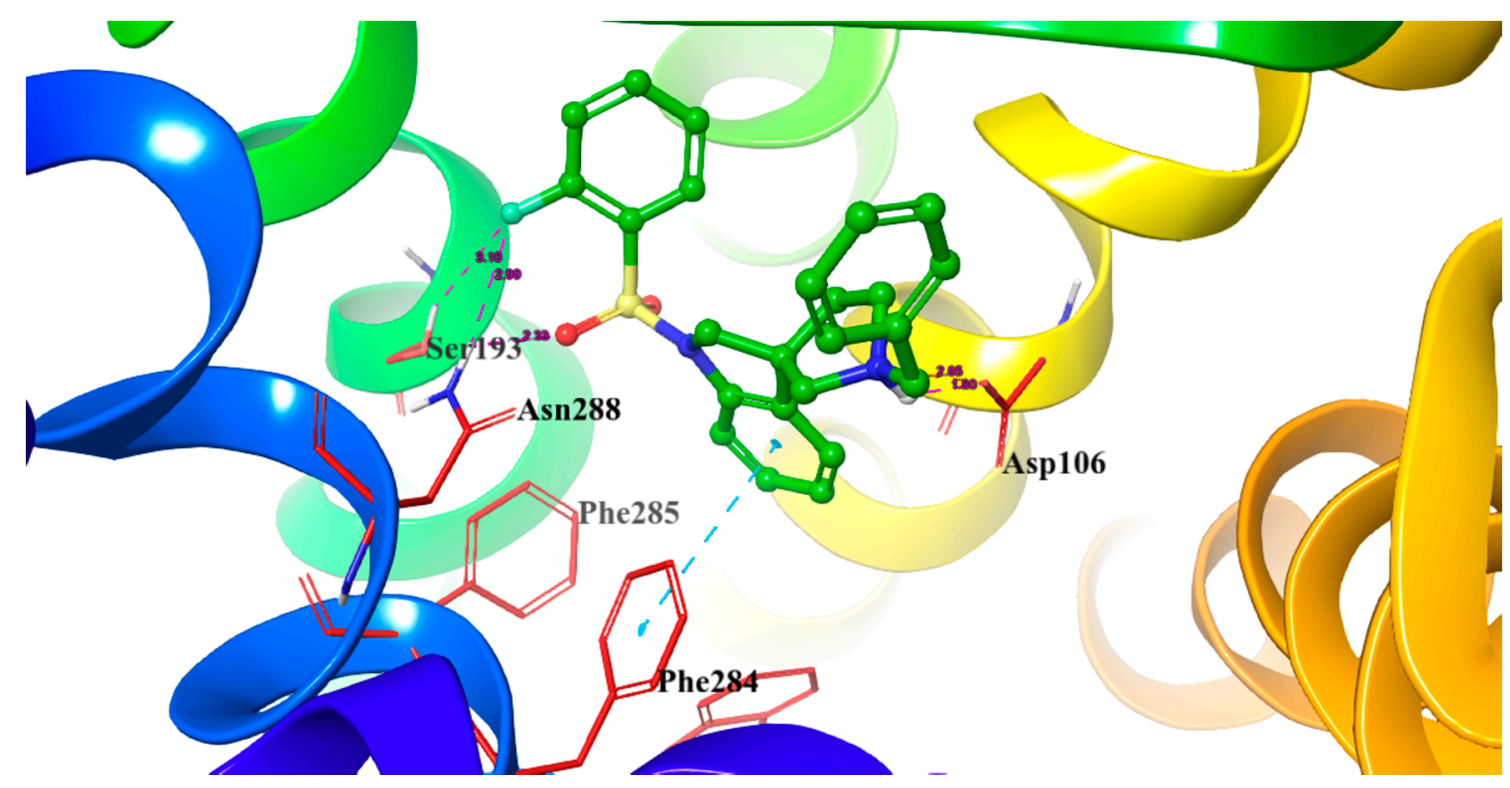

Figure 5. Binding mode of compound 46a in the orthosteric pocket of 5-HT $\mathrm{H}_{6} \mathrm{R}$.

The indoline core occupies the primary hydrophobic cavity of the binding pocket (formed by $\operatorname{Trp} 281^{6.48}$, Phe $284^{6.51}$, Phe $285^{6.52}$ ), while the protonated quaternary pyrrolidine-nitrogen is oriented towards the conserved Asp106 3.32 , forming a well-established hydrogen bond. The phenyl-sulfonyl moiety of 46a is sitting at a secondary hydrophobic cleft defined by Val107 $7^{3.33}$, Ala157 ${ }^{4.56}$, Leu160 4.59 , Pro160 4.60 and Leu164 $4^{4.63}$, positioning the sulfonyl-linker as hydrogen-bond acceptor against Ser $193^{5.43}$ and Asn288 6.55 . Interestingly, the fluorine atom as hydrogen bond acceptor is offering a possible polar interaction with the Asn $288^{6.55}$ residue, underlining the preference of the ortho-substitution at the phenyl-sulfonyl ring.

\section{Conclusions}

The structure-activity relationship around the original spiropyrrolidinyl-oxindole hit (6) was first investigated using the "SAR-by-catalog" approach that resulted in some moderate improvement in affinity and a low level of selectivity. Therefore, we decided to explore the novel 5- $\mathrm{HT}_{6} \mathrm{R}$ chemotype by a more conventional medicinal chemistry strategy. A synthetic tree (summarized in Scheme 8) of the synthesized oxindoles and indoles was elaborated starting from the core tryptoline intermediate (25).

The removal of the bulky lipophilic site at the 2'-position of the pyrrolidine ring and insertion of the classical phenylsulfonyl part resulted in notable selectivity across the serotoninergic GPCR panel of 4 receptors. The next optimization step was analyzing the chemistry of known indole, indoline and oxindole-based 5- $\mathrm{HT}_{6} \mathrm{R}$ inhibitors in ChEMBL. We have synthesized different 1-(phenylsulfonyl) indolines, being substituted in the $1^{\prime}$-pyrrolidine nitrogen with either basic-nitrogen containing, or lipophilic groups. As a result, $1^{\prime}$-benzyl-1-(phenylsulfonyl) spiro[indoline-3,3'-pyrrolidine] (39a) and its corresponding 2-, 3-substituted analogues $46 \mathbf{a}-\mathbf{b}$ were identified as $5-\mathrm{HT}_{6} \mathrm{R}$ starting points. This opened a new chemical space for the under-represented spiro[pyrrolidine-3,3'-indoline] chemotype. 

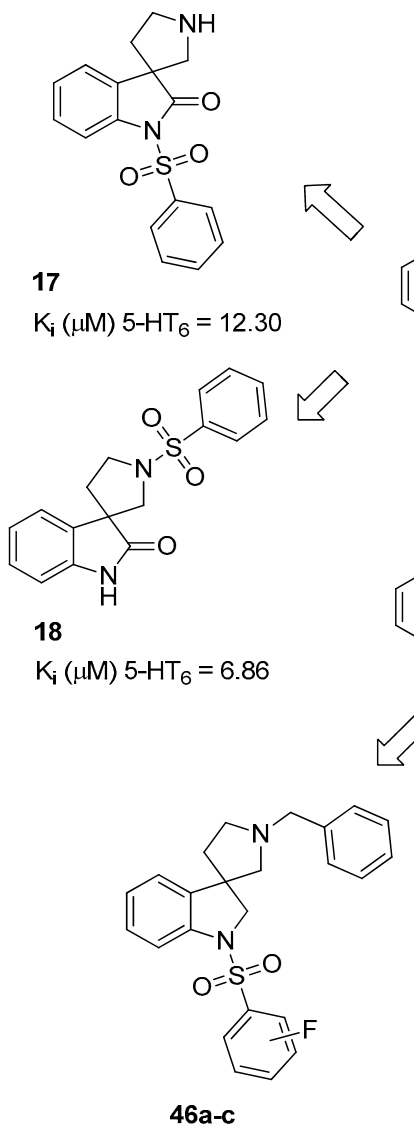

46a-c

46a $\mathrm{K}_{\mathrm{i}}(\mu \mathrm{M}) 5-\mathrm{HT}_{6}=0.19$
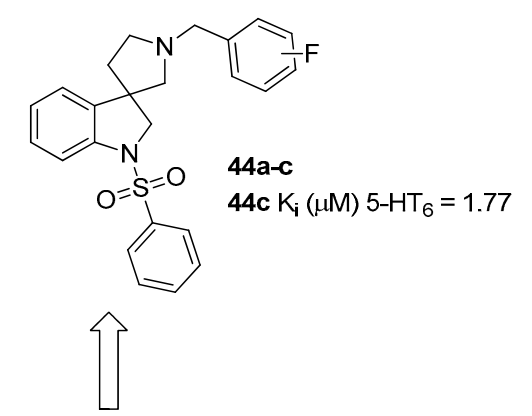<smiles>c1ccc2c3c([nH]c2c1)CCNC3</smiles><smiles>C1=CC=CC=1</smiles><smiles>O=S(=O)(c1ccccc1)N1CC2(CCN(Cc3ccncc3)C2)c2ccccc21</smiles>

$\mathrm{K}_{\mathrm{i}}(\mu \mathrm{M}) 5-\mathrm{HT}_{6}=6.60$<smiles>c1ccc(CN2CCC3(CNc4ccccc43)C2)cc1</smiles>

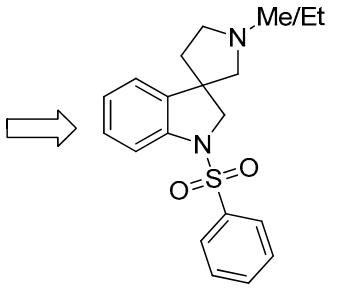

40a-b

$40 \mathbf{a ~} \mathrm{K}_{\mathbf{i}}(\mu \mathrm{M}) 5-\mathrm{HT}_{6}=1.85$

Scheme 8. Spiro[pyrrolidine-3,3'-oxindoles] and spiro[pyrrolidine-3,3'-indolines] as 5HT6 ligands.

\section{Materials and Methods}

All chemical reagents used were purchased from commercial chemical suppliers. The NMR experiments were performed at $500 \mathrm{MHz}\left({ }^{1} \mathrm{H}\right)$ on a Varian VNMR SYSTEM spectrometer. Chemical shifts are referenced to the residual solvent signals, $2.50 \mathrm{ppm}$ for ${ }^{1} \mathrm{H}$ in DMSO- $d_{6}$ and $7.28 \mathrm{ppm}$ for ${ }^{1} \mathrm{H}$ in $\mathrm{CDCl}_{3}$. The MS measurements were performed on Shimadzu LCMS2020 LC/MS system. Flash chromatography was performed using Teledyne ISCO CombiFlash Lumen+ Rf. Purifications by preparative-HPLC were performed with Hanbon NS4205 Binary high pressure semi-preparative HPLC. Thin-layer chromatography was performed on TLC Silica Gel 60 F254. High resolution mass spectrometric measurements were performed using a Q-TOF Premier mass spectrometer (Waters Corporation, Milford, MA, USA) in positive electrospray ionization mode. Compounds 7-16 were purchased from Mcule Inc. 
4.1. General Procedures for the Synthesis of Spiro[pyrrolidine-3,3'-oxindole] and Spiro[pyrrolidine-3,3'-indoline] Derivatives

4.1.1. Procedures to Afford 1-(Phenylsulfonyl)spiro[indoline-3,3'-pyrrolidin]-2-one (17)

Synthesis of Benzyl 2-Oxospiro[indoline-3,3'-pyrrolidine]-1'-carboxylate (27)

To the solution of benzyl 3,4-dihydro-1H-pyrido[3,4- $b$ ]indole-2(9H)-carboxylate (26) (918 mg, $3 \mathrm{mmol})$ in $10 \mathrm{~mL}$ tetrahydrofuran was added $10 \mathrm{~mL}$ distilled water and triethylamine $(0.436 \mathrm{~mL}$, $3.15 \mathrm{mmol}, 1.05$ equiv.) at room temperature. Afterwards $N$-chlorosuccinimide (431 mg, $3.24 \mathrm{mmol}$, 1.08 equiv.) was added at $0{ }^{\circ} \mathrm{C}$ in portions. The reaction mixture was stirred for $1.5 \mathrm{~h}$ at room temperature. The reaction mixture was diluted with $10 \mathrm{~mL}$ brine and was extracted using $2 \times 10 \mathrm{~mL}$ ethyl acetate. The combined organic phases were dried over sodium-sulfate, filtered and evaporated under reduced pressure. The crude material was purified using flash chromatography (gradient: dichloromethane: methanol $0 \%$ to 5\% methanol) to give 27 as a yellow solid. Yield: $399 \mathrm{mg}$ (41\%). ${ }^{1} \mathrm{H}-\mathrm{NMR}\left(500 \mathrm{MHz}, \mathrm{DMSO}-d_{6}\right) \delta$ ppm 7.42-7.28 (m, 8H, ArH-benzyl, ArH-4, ArH-5, ArH-6), 7.14 $(\mathrm{d}, J=7.8 \mathrm{~Hz}, 1 \mathrm{H}, \mathrm{ArH}-7), 5.11\left(\mathrm{~s}, 2 \mathrm{H}\right.$, benzyl $\left.\mathrm{CH}_{2}\right), 3.70-3.53(\mathrm{~m}, 4 \mathrm{H}$, pyrrolidine H-2' , pyrrolidine H-5') , 2.19-2.05 (m, 2H, H-4' $) .{ }^{13} \mathrm{C}-\mathrm{NMR}\left(125 \mathrm{MHz}, \mathrm{DMSO}-d_{6}\right) \delta \mathrm{ppm} 176.9(\mathrm{C}-2), 154.8(\mathrm{C}=\mathrm{O}), 142.8$ (C-3a), 141.5 (C-7a), 135.9 (benzyl C-1), 128.5 (benzyl C-3, benzyl C-5), 127.9 (benzyl C-4, benzyl C-2, benzyl C-6), 123.8 (C-4), 122.1 (C-5), 109.3 (C-7), 67.9 (benzyl $\mathrm{CH}_{2}$ ), 57.7 (C-3), 45.1 (pyrrolidine C-2'), 43.3 (pyrrolidine $\mathrm{C}-5^{\prime}$ ), 34.2 (pyrrolidine C-4'). MS (DUIS+) $m / z 323[\mathrm{M}+\mathrm{H}]^{+}$.

Synthesis of Benzyl 2-oxo-1-(phenylsulfonyl)spiro[indoline-3,3'-pyrrolidine]-1'-carboxylate (28)

(1) Procedure Using Sodium-Hydride

To the solution of benzyl 2-oxospiro[indoline-3,3'-pyrrolidine]-1'-carboxylate (27) (175 mg, $0.542 \mathrm{mmol})$ in $5 \mathrm{~mL}$ anhydrous tetrahydrofuran was added sodium-hydride $(60 \%, 28 \mathrm{mg}, 0.705 \mathrm{mmol}$; 1.3 equiv.) at $0{ }^{\circ} \mathrm{C}$. After stirring the reaction mixture at room temperature for $0.5 \mathrm{~h}$, benzenesulfonyl chloride $\left(0.076 \mathrm{~mL}, 0.596 \mathrm{mmol}, 1.1\right.$ equiv.) was added dropwise at $0{ }^{\circ} \mathrm{C}$. The reaction mixture was stirred overnight at room temperature, then it was quenched by $10 \mathrm{~mL}$ brine and was extracted using ethyl acetate $(2 \times 10 \mathrm{~mL})$. The collected organic phases were dried using sodium sulfate, filtered and evaporated under reduced pressure. The crude product was purified using flash chromatography (gradient: hexane: ethyl acetate $0 \%$ to $20 \%$ ) to afford 28 as a colorless solid. Yield: $94 \mathrm{mg}(38 \%)$.

(2) Procedure Using Lithium-Hexamethyl-Disilazane

To the solution of benzyl 2-oxospiro[indoline-3,3'-pyrrolidine]-1'-carboxylate (27) (161 mg, $0.5 \mathrm{mmol})$ and benzenesulfonyl chloride $(0.076 \mathrm{~mL}, 0.6 \mathrm{mmol}, 1.2$ equiv.) in $5 \mathrm{~mL}$ anhydrous tetrahydrofuran was added lithiumhexamethyl-disilazane (1M in THF, $0.85 \mathrm{~mL}, 0.85 \mathrm{mmol}, 1.7$ equiv.) at $0{ }^{\circ} \mathrm{C}$ and the reaction mixture was stirred at this temperature for $0.5 \mathrm{~h}$. After quenching the reaction by $10 \mathrm{~mL}$ brine, the reaction mixture was extracted using ethyl acetate $(2 \times 10 \mathrm{~mL})$ and the collected organic phases were dried over sodium sulfate, filtered and evaporated under reduced pressure. The crude product was purified using flash chromatography (gradient: hexane: ethyl acetate $0 \%$ to $20 \%$ ) to give 28 as a white solid. Yield: $230 \mathrm{mg}(99 \%) .{ }^{1} \mathrm{H}-\mathrm{NMR}$ (500 MHz, DMSO- $\left.d_{6}\right) \delta \mathrm{ppm} 8.02(\mathrm{~d}$, $J=7.7$ Hz, 2H, ArH-3", ArH-5"), 7.77 (m, 2H, ArH-4", ArH-7), 7.67 (m, 2H, phenyl-sulfonyl ArH-2", phenyl-sulfonyl ArH-6"), 7.43-7.30 (m, 7H, ArH-4, ArH-6, benzyl ArH-2,3,4,5,6), 7.23 (t, J = 7.4 Hz, 1H, ArH-5), $5.09\left(\mathrm{~m}, 2 \mathrm{H}\right.$, benzyl $\left.\mathrm{CH}_{2}\right), 3.65-3.50\left(\mathrm{~m}, 4 \mathrm{H}\right.$, pyrrolidine $\mathrm{H}-2^{\prime}$, pyrrolidine $\left.\mathrm{H}-5^{\prime}\right), 2.25-2.09(\mathrm{~m}$, 2H, pyrrolidine H-4 $\left.{ }^{\prime}\right) .{ }^{13} \mathrm{C}-\mathrm{NMR}\left(125 \mathrm{MHz}, \mathrm{DMSO}-d_{6}\right) \delta$ ppm $170.1(\mathrm{C}-2), 154.3(\mathrm{C}=\mathrm{O}), 136.2$ (benzyl C-1), 135.5 (C-7a), 134.8 (phenyl-sulfonyl C-1"), 133.9 (C-3a), 133.1 (phenyl-sulfonyl C-4"), 129.2 (C-3", C-5"), 128.5 (benzyl C-3, benzyl C-5), 128.0 (C-6, benzyl C-4), 127.5 (benzyl C-2, benzyl C-6), 127.4 (C-2" , C-6"), 123.3 (C-4), 121.8 (C-5), 113.8 (C-7), 67.5 (benzyl CH 2$), 66.1(\mathrm{C}-3), 46.4\left(\mathrm{C}-2^{\prime}\right), 46.1\left(\mathrm{C}-5^{\prime}\right)$, $30.3\left(\mathrm{C}-4^{\prime}\right)$. MS (DUIS+) $m / z 463[\mathrm{M}+\mathrm{H}]^{+}$. 
Synthesis of 1-(Phenylsulfonyl)spiro[indoline-3,3'-pyrrolidin]-2-one (17)

To the solution of benzyl 2-oxo-1-(phenylsulfonyl)spiro[indoline-3,3'-pyrrolidine]-1'-carboxylate (28) (180 mg, $0.389 \mathrm{mmol})$ in methanol was added palladium (10\%) on charcoal (90 mg, $5 \mathrm{w} / \mathrm{w} \%)$ in an autoclave. The reactor was filled with $5 \mathrm{~atm}$ hydrogen gas and was stirred for $1 \mathrm{~h}$ at room temperature. The reaction mixture was then filtered on Celite and was evaporated under reduced pressure. The crude material was purified by flash chromatography (gradient: dichloromethane: methanol $0 \%$ to $5 \%$ methanol) to give 17 as an orange solid. Yield: $108 \mathrm{mg}(85 \%) .{ }^{1} \mathrm{H}-\mathrm{NMR}(500 \mathrm{MHz}$, $\left.\mathrm{CDCl}_{3}\right) \delta$ ppm $8.10(\mathrm{~d}, J=8.0 \mathrm{~Hz}, 2 \mathrm{H}$, phenyl-sulfonyl ArH-3", phenyl-sulfonyl ArH-5"), $7.91(\mathrm{~d}$, $J=8.4 \mathrm{~Hz}, 1 \mathrm{H}$, phenyl-sulfonyl ArH-4"), $7.65(\mathrm{t}, J=7.2 \mathrm{~Hz}, 1 \mathrm{H}, \operatorname{ArH}-7), 7.53(\mathrm{t}, J=7.2 \mathrm{~Hz}, 2 \mathrm{H}$, phenyl-sulfonyl ArH-2", phenyl-sulfonyl ArH-6"), $7.47(\mathrm{~d}, J=7.2 \mathrm{~Hz}, 1 \mathrm{H}, \mathrm{ArH}-4), 7.32(\mathrm{t}, J=8.0$ $\mathrm{Hz}, 1 \mathrm{H}, \mathrm{ArH}-6), 7.19$ (t, $J=8.0 \mathrm{~Hz}, 1 \mathrm{H}, \mathrm{ArH}-5), 3.08\left(\mathrm{~m}, 1 \mathrm{H}, \mathrm{H}-2^{\prime}\right), 2.93\left(\mathrm{~m}, 1 \mathrm{H}\right.$, pyrrolidine $\left.\mathrm{H}-2^{\prime}\right)$, 2.74-2.69 $\left(\mathrm{m}, 2 \mathrm{H}\right.$, pyrrolidine $\left.\mathrm{H}-5^{\prime}\right), 2.28-2.23\left(\mathrm{~m}, 1 \mathrm{H}\right.$, pyrrolidine $\left.\mathrm{H}-4^{\prime}\right), 2.11-2.04(\mathrm{~m}, 1 \mathrm{H}$, pyrrolidine H-4'). ${ }^{13} \mathrm{C}-\mathrm{NMR}\left(125 \mathrm{MHz}, \mathrm{DMSO}-d_{6}\right) \delta$ ppm 175.2 (C-2), 166.8 (C-7a), 140.4 (phenyl-sulfonyl C-1"), 135.2 (C-3a), 133.0 (phenyl-sulfonyl C-4"), 129.5 (phenyl-sulfonyl C-3", phenyl-sulfonyl C-5"), 128.4 (C-6), 127.1 (phenyl-sulfonyl C-2", phenyl-sulfonyl C-6"), 122.5 (C-4), 121.7 (C-5), 109.6 (C-7), 55.8 (C-3), 48.3 (pyrrolidine C-2' $), 47.2$ (pyrrolidine C-5'), 33.0 (pyrrolidine C-4'). MS (DUIS+) $\mathrm{m} / z 329$ $[\mathrm{M}+\mathrm{H}]^{+}$. HRMS (ESI+): $m / z[\mathrm{M}+\mathrm{H}]^{+}$calcd. for $\mathrm{C}_{17} \mathrm{H}_{17} \mathrm{~N}_{2} \mathrm{O}_{3} \mathrm{~S}: 329.0960$; found: 329.0949 .

\subsubsection{Synthesis of $1^{\prime}$-(Phenylsulfonyl)spiro[indoline-3,3'-pyrrolidin]-2-one (18)}

To the solution of 2-(phenylsulfonyl)-2,3,4,9-tetrahydro- $1 H$-pyrido[3,4-b]indole (29) (312 mg, $1 \mathrm{mmol})$ in tetrahydrofuran: water $(10: 10 \mathrm{~mL})$ was added $10 \mathrm{~mL}$ glacial acetic acid at $0{ }^{\circ} \mathrm{C}$. $\mathrm{N}$-bromosuccinimide ( $178 \mathrm{mg}, 1 \mathrm{mmol}, 1$ equiv.) was added slowly in portions at $0{ }^{\circ} \mathrm{C}$. The reaction mixture was stirred for $1.5 \mathrm{~h}$ at $0{ }^{\circ} \mathrm{C}$. Afterwards the reaction was quenched at $0{ }^{\circ} \mathrm{C}$ by $10 \mathrm{~mL}$ concentrated sodium-carbonate solution and was stirred for $0.5 \mathrm{~h}$, allowing to warm up to room temperature. The mixture was extracted using ethyl acetate $(2 \times 10 \mathrm{~mL})$. The combined organic phases were washed with concentrated sodium-hydrogen carbonate $(2 \times 10 \mathrm{~mL})$ and by brine $(2 \times$ $10 \mathrm{~mL}$ ). The organic phases were dried over sodium-sulfate, filtered and evaporated under reduced pressure. The crude product was purified using flash chromatography (gradient: hexane: ethyl acetate $0 \%$ to $20 \%$ ethyl acetate) to afford 18 as a colorless solid. Yield: $180 \mathrm{mg}(55 \%) .{ }^{1} \mathrm{H}-\mathrm{NMR}$ $\left(500 \mathrm{MHz}, \mathrm{DMSO}-d_{6}\right) \delta \mathrm{ppm} 10.47(\mathrm{~s}, 1 \mathrm{H}, \mathrm{NH}), 7.87(\mathrm{~d}, J=7.3 \mathrm{~Hz}, 2 \mathrm{H}$, phenyl-sulfonyl ArH-3", ArH-5"), $7.76(\mathrm{t}, J=7.3 \mathrm{~Hz}, 1 \mathrm{H}$, phenyl-sulfonyl ArH-4"), $7.67(\mathrm{t}, J=7.3 \mathrm{~Hz}, 2 \mathrm{H}$, phenyl-sulfonyl ArH-2", phenyl-sulfonyl ArH-6"), $7.15(\mathrm{t}, J=7.3 \mathrm{~Hz}, 1 \mathrm{H}, \mathrm{ArH}-4), 6.82(\mathrm{t}, J=8.5 \mathrm{~Hz}, 2 \mathrm{H}, \operatorname{ArH}-5$, ArH-6), $6.69\left(\mathrm{~d}, J=7.3 \mathrm{~Hz}, 1 \mathrm{H}\right.$, ArH-7), $3.56\left(\mathrm{t}, J=6.7 \mathrm{~Hz}, 1 \mathrm{H}\right.$, pyrrolidine $\left.\mathrm{H}-2^{\prime}\right), 3.35(\mathrm{t}, J=7.3 \mathrm{~Hz}$, $1 \mathrm{H}$, pyrrolidine $\left.\mathrm{H}-2^{\prime}\right), 3.35\left(\mathrm{~d}, J=3.5 \mathrm{~Hz}, 2 \mathrm{H}\right.$, pyrrolidine $\left.\mathrm{H}-5^{\prime}\right), 2.10-2.05\left(\mathrm{~m}, 1 \mathrm{H}\right.$, pyrrolidine $\left.\mathrm{H}-4^{\prime}\right)$, 1.94-1.88 (m, $1 \mathrm{H}$, pyrrolidine H-4'). ${ }^{13} \mathrm{C}-\mathrm{NMR}\left(125 \mathrm{MHz}\right.$, DMSO- $\left.d_{6}\right) \delta$ ppm $181.4(\mathrm{C}-2), 167.0(\mathrm{C}-3 \mathrm{a})$, 141.3 (C-7a), 135.8 (phenyl-sulfonyl C-1"), 133.3 (phenyl-sulfonyl C-4"), 129.5 (phenyl-sulfonyl C-3", phenyl-sulfonyl C-5"), 128.3 (C-6), 127.4 (phenyl-sulfonyl C-2", phenyl-sulfonyl C-6"), 122.4 (C-4), 121.8 (C-5), 109.6 (C-7), 55.6 (C-3), 47.4 (pyrrolidine C-2', pyrrolidine C-5'), 35.8 (pyrrolidine C-4'). MS (DUIS+) $m / z 329[\mathrm{M}+\mathrm{H}]^{+}$. HRMS (ESI+): $m / z[\mathrm{M}+\mathrm{H}]^{+}$calcd. for $\mathrm{C}_{17} \mathrm{H}_{17} \mathrm{~N}_{2} \mathrm{O}_{3} \mathrm{~S}: 329.0960$; found: 329.0957.

\subsubsection{Procedures to Afford 1'-Benzyl-1-(phenylsulfonyl)spiro[indoline-3,3'-pyrrolidine] (39a)}

To the solution of 1'-benzylspiro[indoline-3,3'-pyrrolidin]-2-one (37a) $(500 \mathrm{mg}, 1.7985 \mathrm{mmol})$ in $15 \mathrm{~mL}$ absolutized tetrahydrofuran was added borane/tetrahydrofuran (1M) complex solution (4.495 mL, $4.495 \mathrm{mmol}, 2.5$ equiv.) and the reaction mixture was refluxed overnight. The reaction was allowed to cool down to room temperature and was quenched using $30 \mathrm{~mL}$ concentrated ammonium-chloride solution and was stirred for $20 \mathrm{~min}$. Afterwards, $20 \mathrm{~mL}$ ethyl acetate was used for extraction. The combined organic phases were dried over sodium-sulfate, filtered and evaporated under reduced pressure to afford $400 \mathrm{mg} \mathrm{38a}$, used as a crude product in the further 
steps without purification. To the solution of crude $1^{\prime}$-benzylspiro[indoline-3,3'-pyrrolidine] (38a) (400 mg $1.513 \mathrm{mmol}$ ) (in anhydrous dichloromethane was added triethylamine $(0.419 \mathrm{~mL}, 3.03 \mathrm{mmol}$, 2 equiv.) and $\mathrm{N}, \mathrm{N}$-dimethylpyridin-4-amine $(10 \mathrm{mg}, 0.076 \mathrm{mmol}, 0.5$ equiv.) at room temperature. Afterwards benzenesulfonyl chloride $(0.203 \mathrm{~mL}, 1.59 \mathrm{mmol}, 1.05$ equiv.) was added to the solution at $5{ }^{\circ} \mathrm{C}$. The reaction mixture was stirred at room temperature overnight. The reaction was quenched using $10 \mathrm{~mL} 10 \% \mathrm{HCl}$ solution and was extracted by $10 \mathrm{~mL}$ dichloromethane. The dichloromethane phase was collected and dried over sodium-sulfate. The drying agent was filtered-off and the solution was evaporated under reduced pressure. The crude product was purified by flash chromatography to afford 39a as yellow oil. Yield: $621 \mathrm{mg}(85 \%$ calculated to $37 \mathrm{a}) .{ }^{1} \mathrm{H}-\mathrm{NMR}\left(500 \mathrm{MHz}, \mathrm{DMSO}-d_{6}\right) \delta \mathrm{ppm}$ $7.73(\mathrm{~d}, J=7.6 \mathrm{~Hz}, 2 \mathrm{H}$, phenyl-sulfonyl H-2", phenyl-sulfonyl H-6"), $7.58(\mathrm{t}, J=7.6 \mathrm{~Hz}, 1 \mathrm{H}, \mathrm{H}-6), 7.46$ $(\mathrm{t}, J=7.9 \mathrm{~Hz}, 3 \mathrm{H}$, phenyl-sulfonyl H-3", phenyl-sulfonyl H-4", phenyl-sulfonyl H-5"), $7.31(\mathrm{t}, J=7.6 \mathrm{~Hz}$, 2H, phenyl-sulfonyl H-3", phenyl-sulfonyl H-5"), 7.27-7.21 (m, 5H, benzyl H-1-5), $7.05(\mathrm{t}, J=7.6 \mathrm{~Hz}$, 1H, H-5), 3.89 (d, J = 10.9 Hz, 1H, H-2), 3.78 (d, J = 10.9 Hz, 1H, H-2), 3.52 (s, 2H, benzyl CH $\mathrm{CH}_{2}$ ), 2.69 $\left(\mathrm{m}, 1 \mathrm{H}\right.$, pyrrolidine $\left.\mathrm{H}-2^{\prime}\right), 2.57\left(\mathrm{~m}, 1 \mathrm{H}\right.$, pyrrolidine $\left.\mathrm{H}-2^{\prime}\right), 2.24\left(\mathrm{~d}, J=9.1 \mathrm{~Hz}, 1 \mathrm{H}\right.$, pyrrolidine $\left.\mathrm{H}-5^{\prime}\right), 2.15$ $\left(\mathrm{d}, J=9.2 \mathrm{~Hz}, 1 \mathrm{H}\right.$, pyrrolidine $\left.\mathrm{H}-5^{\prime}\right), 1.91-1.85\left(\mathrm{~m}, 1 \mathrm{H}\right.$, pyrrolidine $\left.\mathrm{H}-4^{\prime}\right), 1.78-1.73(\mathrm{~m}, 1 \mathrm{H}$, pyrrolidine H-4'). ${ }^{13}$ C-NMR (125 MHz, DMSO- $d_{6}$ ) $\delta$ ppm 141.0 (C-3a), 139.0 (C-7a), 134.2 (benzyl C-1), 129.8 (phenyl-sulfonyl C-1"), 129.8 (phenyl-sulfonyl C-4"), 128.7 (phenyl-sulfonyl C-3", phenyl-sulfonyl C-5"), 128.7 (benzyl C-3, benzyl C-5), 127.4 (benzyl C-2, benzyl C-6), 127.4 (C-6), 124.9 (phenyl-sulfonyl C-2", phenyl-sulfonyl C-6", benzyl C-4), 124.2 (C-4), 121.8 (C-5), 114.6 (C-7), 66.7 (pyrrolidine C-2'), 63.5 (benzyl CH$_{2}$ ), 59.3 (C-3), 53.3 (pyrrolidine C-5'), $49.8\left(\mathrm{C}-4^{\prime}\right)$. MS (DUIS+) $m / z 405[\mathrm{M}+\mathrm{H}]^{+}$. HRMS (ESI+): $m / z[\mathrm{M}+\mathrm{H}]^{+}$calcd. for $\mathrm{C}_{24} \mathrm{H}_{25} \mathrm{~N}_{2} \mathrm{O}_{2} \mathrm{~S}: 405.1637$; found: 405.1620 .

4.1.4. Procedures to Afford 1-(Phenylsulfonyl)-1'-(pyridin-4-ylmethyl)spiro[indoline-3,3'-pyrrolidine] (39b)

Synthesis of 1'-(Pyridin-4-ylmethyl)spiro[indoline-3,3'-pyrrolidin]-2-one (37b)

To the solution of the crude 2-(pyridin-4-ylmethyl)-2,3,4,9-tetrahydro- $1 H$-pyrido[3,4-b]indole (36b) $(812 \mathrm{mg})$ in tetrahydrofuran:water $(10: 10 \mathrm{~mL})$ was added $10 \mathrm{~mL}$ glacial acetic acid at $0{ }^{\circ} \mathrm{C}$. $\mathrm{N}$-bromosuccinimide $(549 \mathrm{mg}, 3.0874 \mathrm{mmol})$ was added slowly in portions at $0{ }^{\circ} \mathrm{C}$. The reaction mixture was stirred for $1.5 \mathrm{~h}$ at $0{ }^{\circ} \mathrm{C}$. Afterwards the reaction was quenched at $0{ }^{\circ} \mathrm{C}$ by $20 \mathrm{~mL}$ concentrated sodium-carbonate solution and was stirred for $0.5 \mathrm{~h}$, allowing to warm up to room temperature. The mixture was extracted using ethyl-acetateethyl acetate $(2 \times 10 \mathrm{~mL})$. The combined organic phases were washed with concentrated sodium-hydrogen carbonate $(2 \times 10 \mathrm{~mL})$ and by brine $(2 \times 10 \mathrm{~mL})$. The organic phases were dried over sodium-sulfate, filtered and evaporated under reduced pressure. The crude product was purified using flash chromatography (gradient: dichloromethane: methanol $0 \%$ to $10 \%$ methanol) to afford $37 \mathrm{~b}$ as a yellow solid. Yield: $293 \mathrm{mg}$ (35\% calculated to 25). ${ }^{1} \mathrm{H}-\mathrm{NMR}\left(500 \mathrm{MHz}, \mathrm{DMSO}-d_{6}\right) \delta \mathrm{ppm} 11.63(\mathrm{~s}, 1 \mathrm{H}, \mathrm{NH}), 8.52(\mathrm{~d}, J=5.6 \mathrm{~Hz}, 2 \mathrm{H}$, pyridine ArH-2, pyridine ArH-6), $7.59(\mathrm{~d}, J=7.2 \mathrm{~Hz}, 1 \mathrm{H}, \mathrm{ArH}-4), 7.40(\mathrm{~d}, J=8.0 \mathrm{~Hz}, 1 \mathrm{H}, \mathrm{ArH}-7), 7.32$ $(\mathrm{d}, J=5.5 \mathrm{~Hz}, 2 \mathrm{H}$, pyridine ArH-3, pyridine ArH-5), $7.23(\mathrm{t}, J=7.6 \mathrm{~Hz}, 1 \mathrm{H}, \mathrm{ArH}-6), 7.05(\mathrm{t}, J=7.3 \mathrm{~Hz}$, $1 \mathrm{H}, \mathrm{ArH}-5), 4.72\left(\mathrm{~s}, 2 \mathrm{H}\right.$, pyridyl-methyl $\left.\mathrm{CH}_{2}\right), 3.65\left(\mathrm{t}, J=6.7 \mathrm{~Hz}, 2 \mathrm{H}\right.$, pyrrolidine $\left.\mathrm{H}-2^{\prime}\right), 3.31(\mathrm{~m}, 2 \mathrm{H}$, pyrrolidine $\left.\mathrm{H}-5^{\prime}\right), 3.02\left(\mathrm{t}, J=6.7 \mathrm{~Hz}, 2 \mathrm{H}\right.$, pyrrolidine $\left.\mathrm{H}-4^{\prime}\right) .{ }^{13} \mathrm{C}-\mathrm{NMR}\left(125 \mathrm{MHz}, \mathrm{DMSO}-d_{6}\right) \delta \mathrm{ppm} 179.3$ $(\mathrm{C}=\mathrm{O}), 148.5$ (pyridine $\mathrm{C}-2$, pyridine $\mathrm{C}-6), 147.2$ (pyridine $\mathrm{C}-1), 141.6$ (C-7a), 134.7 (C-3a), 128.1 (C-6), 123.5 (C-4), 122.4 (pyridine C-3, pyridine C-5), 109.7 (C-7), 61.2 (pyridyl-methylene $\mathrm{CH}_{2}$ ), $60.1(\mathrm{C}-3$ ), 54.4 (pyrrolidine C-2'), 53.6 (pyrrolidine C-5'), 34.7 (pyrrolidine C-4'). MS (DUIS+) $m / z 280[\mathrm{M}+\mathrm{H}]^{+}$.

Synthesis of 1-(Phenylsulfonyl)-1'-(pyridin-4-ylmethyl)spiro[indoline-3,3'-pyrrolidine] (39b)

To the solution of $1^{\prime}$-(pyridin-4-ylmethyl)spiro[indoline-3,3'-pyrrolidin]-2-one (37b) (289 mg, $1.05 \mathrm{mmol}$ ) in $10 \mathrm{~mL}$ anhydrousdry tetrahydrofuran was added borane/tetrahydrofuran $(1 \mathrm{M})$ complex solution $(2.63 \mathrm{~mL}, 2.63 \mathrm{mmol}, 2.5$ equiv.) and the reaction mixture was refluxed overnight. The reaction was allowed to cool down to room temperature and was quenched using $15 \mathrm{~mL}$ concentrated ammonium-chloride solution and was stirred for $20 \mathrm{~min}$. Afterwards, $10 \mathrm{~mL}$ ethyl acetate was used 
for extraction. The combined organic phases were dried over sodium-sulfate, filtered and evaporated under reduced pressure to afford $292 \mathrm{mg} \mathrm{38b}$, used as a crude product in the further steps without purification. To the solution of crude $1^{\prime}$-(pyridin-4-ylmethyl)spiro[indoline-3,3'-pyrrolidine] (38b) (0.292 $\mathrm{mg})$ in $5 \mathrm{~mL}$ anhydrous dichloromethane was added triethylamine $(0.307 \mathrm{~mL}, 2.22 \mathrm{mmol})$ and $N, N$-dimethylpyridin-4-amine $(6.8 \mathrm{mg}, 0.0555 \mathrm{mmol})$ at room temperature. Afterwards benzenesulfonyl chloride ( $204 \mathrm{mg}, 1.161 \mathrm{mmol}$ ) was added to the solution at $5{ }^{\circ} \mathrm{C}$. The reaction mixture was stirred at room temperature overnight. The reaction was quenched using $10 \mathrm{~mL} 10 \% \mathrm{HCl}$ solution and was extracted by $5 \mathrm{~mL}$ dichloromethane. The dichloromethane phase was collected and dried over sodium-sulfate. The drying agent was filtered-off and the solution was evaporated under reduced pressure. The crude product was purified by flash chromatography to afford $39 \mathrm{~b}$ as yellow solid. Yield: $0.003 \mathrm{mg} .{ }^{1} \mathrm{H}-\mathrm{NMR}\left(500 \mathrm{MHz}\right.$, DMSO- $\left.d_{6}\right) \delta \mathrm{ppm} 8.50(\mathrm{~d}, J=6.2 \mathrm{~Hz}, 2 \mathrm{H}$, pyridine ArH-2, pyridine ArH-6), 7.72 (d, $J=7.9 \mathrm{~Hz}, 2 \mathrm{H}$, phenyl-sulfonyl ArH-2", phenyl-sulfonyl ArH-6"), 7.58-7.53 (m, 3H, pyridine ArH-3, pyridine ArH-5, phenyl-sulfonyl ArH-4"), 7.49 (d, J = 7.8 Hz, 1H, ArH-7), 7.43 $(\mathrm{t}, J=8.0 \mathrm{~Hz}, 2 \mathrm{H}$, phenyl-sulfonyl ArH-3", phenyl-sulfonyl ArH-5"), 7.28-7.23 (m, 2H, ArH-4, ArH-6), $7.07(\mathrm{t}, J=7.1 \mathrm{~Hz}, 1 \mathrm{H}, \mathrm{ArH}-5), 3.90\left(\mathrm{~d}, J=11.1 \mathrm{~Hz}, 1 \mathrm{H}\right.$, pyridyl methyl $\left.\mathrm{CH}_{2}\right), 3.83(\mathrm{~d}, J=11.1 \mathrm{~Hz}$, $1 \mathrm{H}$, pyridyl methyl $\left.\mathrm{CH}_{2}\right), 3.74(\mathrm{~d}, J=15.2 \mathrm{~Hz}, 1 \mathrm{H}, \mathrm{H}-2), 3.67(\mathrm{~d}, J=15.2 \mathrm{~Hz}, 1 \mathrm{H}, \mathrm{H}-2), 2.77(\mathrm{~m}, 1 \mathrm{H}$, pyrrolidine $\left.\mathrm{H}-2^{\prime}\right), 2.62\left(\mathrm{~m}, 1 \mathrm{H}\right.$, pyrrolidine $\left.\mathrm{H}-2^{\prime}\right), 2.17\left(\mathrm{~m}, 2 \mathrm{H}\right.$, pyrrolidine $\left.\mathrm{H}-5^{\prime}\right), 1.95-1.89(\mathrm{~m}, 1 \mathrm{H}$, pyrrolidine $\left.\mathrm{H}-4^{\prime}\right), 1.82-1.78\left(\mathrm{~m}, 1 \mathrm{H}\right.$, pyrrolidine $\left.\mathrm{H}-4^{\prime}\right) .{ }^{13} \mathrm{C}-\mathrm{NMR}\left(125 \mathrm{MHz}\right.$, DMSO- $\left.d_{6}\right) \delta \mathrm{ppm} 148.6$ (pyridine C-2, pyridine C-6), 141.0 (pyridine C-1), 143.9 (C-3a), 143.1 (C-7a), 139.5 (phenyl-sulfonyl C-1"), 134.1 (phenyl-sulfonyl C-4"), 130.0 (phenyl-sulfonyl C-3," phenyl-sulfonyl C-5"), 128.1 (C-6), 127.3 (phenyl-sulfonyl C-2", phenyl-sulfonyl C-6"), 127.6 (C-4), 124.2 (pyridine C-3, pyridine C-5), 124.8 (C-5), 114.1 (C-7), 65.6 (pyrrolidine $\mathrm{C}-2^{\prime}$ ), 61.5 (benzyl $\mathrm{CH}_{2}$ ), 60.1 (C-2), 53.0 (C-3), 51.3 (pyrrolidine C-5'), 32.9 (pyrrolidine C-4'). MS (DUIS+) $m / z 406$ [M + H] $]^{+}$. HRMS (ESI+): $m / z[\mathrm{M}+\mathrm{H}]^{+}$calcd. for $\mathrm{C}_{23} \mathrm{H}_{24} \mathrm{~N}_{3} \mathrm{O}_{2} \mathrm{~S}$ : 406.1589; found: 406.1586 .

\subsubsection{Synthesis of 1'-Methyl-1-(phenylsulfonyl)spiro[indoline-3,3'-pyrrolidine] (40a)}

The solution of 1'-benzyl-1-(phenylsulfonyl)spiro[indoline-3,3'-pyrrolidine] (39a) (2 mg, $0.495 \mathrm{mmol})$ in $5 \mathrm{~mL}$ methanol was filled into an autoclave. Palladium $(10 \%)$ on charcoal $(100 \mathrm{mg}$, $5 w / w \%)$ was added to the solution and reaction was stirred overnight under 5 bar hydrogen atmosphere at $50{ }^{\circ} \mathrm{C}$. The reaction mixture was filtered through a pad of Celite and was evaporated under reduced pressure. The crude residual was purified by flash chromatography (gradient: dichloromethane: methanol $0 \%$ to $10 \%$ methanol) to afford 40a as a colorless solid. Yield: $37 \mathrm{mg}(23 \%)$. ${ }^{1} \mathrm{H}-\mathrm{NMR}\left(500 \mathrm{MHz}\right.$, DMSO- $\left.d_{6}\right) \delta$ ppm $7.79(\mathrm{~d}, J=7.5 \mathrm{~Hz}, 2 \mathrm{H}$, phenyl-sulfonyl ArH-2", phenyl-sulfonyl ArH-6"), $7.66(\mathrm{t}, J=7.2 \mathrm{~Hz}, 1 \mathrm{H}$, phenyl-sulfonyl ArH-4"), $7.56(\mathrm{t}, J=7.9 \mathrm{~Hz}, 2 \mathrm{H}$, phenyl-sulfonyl ArH-3", phenyl-sulfonyl ArH-5"), 7.48 (d, J = 7.9 Hz, 1H, ArH-7), 7.22 (m, 2H, ArH-4, H-6), 7.03 $(\mathrm{t}, J=7.9 \mathrm{~Hz}, 1 \mathrm{H}, \operatorname{ArH}-5), 3.87(\mathrm{~d}, J=11.8 \mathrm{~Hz}, 1 \mathrm{H}, \mathrm{H}-2), 3.75(\mathrm{~d}, J=11.8 \mathrm{~Hz}, 1 \mathrm{H}, \mathrm{H}-2), 2.62(\mathrm{~m}$, $1 \mathrm{H}$, pyrrolidine $\left.\mathrm{H}-2^{\prime}\right), 2.44\left(\mathrm{~m}, 1 \mathrm{H}\right.$, pyrrolidine $\left.\mathrm{H}-2^{\prime}\right), 2.24\left(\mathrm{~d}, J=9.1 \mathrm{~Hz}, 1 \mathrm{H}\right.$, pyrrolidine $\left.\mathrm{H}-5^{\prime}\right), 2.17$ (s, $3 \mathrm{H}$, methyl $\left.\mathrm{CH}_{3}\right), 2.15\left(\mathrm{~d}, J=9.1 \mathrm{~Hz}, 1 \mathrm{H}\right.$, pyrrolidine $\left.\mathrm{H}-5^{\prime}\right), 1.85-1.80\left(\mathrm{~m}, 1 \mathrm{H}\right.$, pyrrolidine $\left.\mathrm{H}-4^{\prime}\right)$, 1.74-1.69 (m, 1H, pyrrolidine H-4 $\left.{ }^{\prime}\right) .{ }^{13} \mathrm{C}-\mathrm{NMR}\left(125 \mathrm{MHz}, \mathrm{DMSO}-d_{6}\right) \delta$ ppm 143.1 (C-3a, C-7a), 133.1 (phenyl-sulfonyl C-1", phenyl-sulfonyl C-4"), 129.2 (phenyl-sulfonyl C-3", phenyl-sulfonyl C-5"), 127.5 (C-6, phenyl-sulfonyl C-2", phenyl-sulfonyl C-6"), 124.1 (C-4), 114.5 (C-5), 110.0 (C-7), 69.1 (pyrrolidine C-2'), 60.2 (pyrrolidine $\mathrm{C}^{-5^{\prime}}$ ), 55.5 (C-3), 52.8 (C-2), 42.3 (pyrrolidine $\mathrm{N}\left(1^{\prime}\right)$-methyl), 32.5 (pyrrolidine C-4'). MS (DUIS+) $m / z 329$ [M + H] $]^{+}$. HRMS (ESI+): $m / z$ [M + H] $]^{+}$calcd. for $\mathrm{C}_{18} \mathrm{H}_{21} \mathrm{~N}_{2} \mathrm{O}_{2} \mathrm{~S}: 343.1324$; found: 343.1320 .

\subsubsection{Synthesis of 1'-Ethyl-1-(phenylsulfonyl)spiro[indoline-3,3'-pyrrolidine] (40b)}

The solution of 1'-benzyl-1-(phenylsulfonyl)spiro[indoline-3,3'-pyrrolidine] (39a) (100 mg, 0.2475 $\mathrm{mmol}$ ) in $5 \mathrm{~mL}$ methanol was filled into an autoclave. Palladium (10\%) on charcoal (500 $\mathrm{mg}, 5 \mathrm{w} / \mathrm{w} \%)$ was added to the solution and reaction was stirred overnight under 5 bar hydrogen atmosphere at $50^{\circ} \mathrm{C}$. The reaction mixture was filtered through a pad of Celite and was evaporated under reduced pressure. 
The crude residual was purified by flash chromatography (gradient: dichloromethane: methanol $0 \%$ to $10 \%$ methanol) to afford $40 \mathrm{~b}$ as a colorless solid. Yield: $19 \mathrm{mg}(22 \%) .{ }^{1} \mathrm{H}-\mathrm{NMR}\left(500 \mathrm{MHz}, \mathrm{DMSO}-d_{6}\right)$ $\delta$ ppm 7.78 (m, 2H, phenyl-sulfonyl ArH-3", phenyl-sulfonyl ArH-5"), 7.66 (m, 1H, phenyl-sulfonyl ArH-4"), 7.56 (m, 2H, phenyl-sulfonyl ArH-2", phenyl-sulfonyl ArH-6") , 7.50-7.47 (m, 1H, ArH-7), 7.24-7.21 (m, 2H, ArH-4, ArH-6), 7.04 (t, J = 7.6 Hz, 1H, ArH-5), 3.86 (d, J = 10.8 Hz, 1H, H-2), 3.75 (d, $J=10.8 \mathrm{~Hz}, 1 \mathrm{H}, \mathrm{H}-2), 2.68\left(\mathrm{~m}, 1 \mathrm{H}\right.$, pyrrolidine $\left.\mathrm{H}-2^{\prime}\right), 2.44\left(\mathrm{~m}, 1 \mathrm{H}\right.$, pyrrolidine $\left.\mathrm{H}-2^{\prime}\right), 2.34(\mathrm{q}, J=6.4 \mathrm{~Hz}$, 2H, ethyl $\left.\mathrm{CH}_{2}\right), 2.24\left(\mathrm{~m}, 1 \mathrm{H}\right.$, pyrrolidine $\left.\mathrm{H}-5^{\prime}\right), 2.11\left(\mathrm{q}, J=8.9 \mathrm{~Hz}, 1 \mathrm{H}\right.$, pyrrolidine $\left.\mathrm{H}-5^{\prime}\right), 1.86-180(\mathrm{~m}$, $1 \mathrm{H}$, pyrrolidine $\left.\mathrm{H}-4^{\prime}\right), 1.73-167\left(\mathrm{~m}, 1 \mathrm{H}\right.$, pyrrolidine $\left.\mathrm{H}-4^{\prime}\right), 0.93\left(\mathrm{t}, J=7.6 \mathrm{~Hz}, 3 \mathrm{H}\right.$, ethyl $\left.\mathrm{CH}_{3}\right) .{ }^{13} \mathrm{C}-\mathrm{NMR}$ (125 MHz, DMSO-d 6 ) $\delta$ ppm 143.3 (C-3a, C-7a), 133.1 (phenyl-sulfonyl C-1", phenyl-sulfonyl C-4"), 129.5 (phenyl-sulfonyl C-3", phenyl-sulfonyl C-5"), 127.7 (C-6, phenyl-sulfonyl C-2", phenyl-sulfonyl C-6") , 124.1 (C-4), 114.1 (C-5), 110.1 (C-7), 69.1 (pyrrolidine C-2'), 60.2 (pyrrolidine C-5'), 55.3 (C-3), 52.1 (C-2), 50.0 (pyrrolidine $\mathrm{N}\left(1^{\prime}\right)$-ethyl $\mathrm{CH}_{2}$ ), 32.5 (pyrrolidine $\mathrm{C}-4^{\prime}$ ), 13.6 (pyrrolidine $\mathrm{N}\left(1^{\prime}\right)$-ethyl $\mathrm{CH}_{3}$ ). MS (DUIS+) $m / z 343[\mathrm{M}+\mathrm{H}]^{+}$. HRMS (ESI+): $m / z[\mathrm{M}+\mathrm{H}]^{+}$calcd. for $\mathrm{C}_{19} \mathrm{H}_{23} \mathrm{~N}_{2} \mathrm{O}_{2} \mathrm{~S}: 343.1480$; found: 343.1496 .

4.1.7. Procedures to Afford $1^{\prime}$-(2-Fluorobenzyl)-1-(phenylsulfonyl)spiro[indoline-3,3'-pyrrolidine] (44a)

Synthesis of $1^{\prime}$-(2-Fluorobenzyl)spiro[indoline-3,3'-pyrrolidin]-2-one (42a)

To the solution of $41 \mathrm{a}(1.54 \mathrm{~g}, 5.5 \mathrm{mmol})$ in tetrahydrofuran: water $(30: 30 \mathrm{~mL})$ was added $30 \mathrm{~mL}$ glacial acetic acid at $0^{\circ} \mathrm{C}$. $\mathrm{N}$-bromosuccinimide $(979 \mathrm{mg}, 5.5 \mathrm{mmol}, 1$ equiv.) was added slowly in portions at $0{ }^{\circ} \mathrm{C}$. The reaction mixture was stirred for $1.5 \mathrm{~h}$ at $0{ }^{\circ} \mathrm{C}$. Afterwards the reaction was quenched at $0^{\circ} \mathrm{C}$ by $40 \mathrm{~mL}$ concentrated sodium-carbonate solution and was stirred for $0.5 \mathrm{~h}$, allowing to warm up to room temperature. The mixture was extracted using ethyl acetate $(2 \times 20 \mathrm{~mL})$. The combined organic phases were washed with concentrated sodium-hydrogen carbonate $(2 \times 20 \mathrm{~mL})$ and by brine $(2 \times 20 \mathrm{~mL})$. The organic phases were dried over sodium-sulfate, filtered and evaporated under reduced pressure. The product 42a was purified by flash chromatography (gradient: dichloromethane: methanol $0 \%$ to $10 \%$ methanol) Yield: $970 \mathrm{mg}(56 \%) .{ }^{1} \mathrm{H}-\mathrm{NMR}\left(500 \mathrm{MHz}, \mathrm{DMSO}-d_{6}\right)$ $\delta$ ppm $10.31(\mathrm{~s}, 1 \mathrm{H}, \mathrm{NH}), 8.01(\mathrm{~d}, J=8.8 \mathrm{~Hz}, 1 \mathrm{H}$, benzyl ArH-6), 7.77 (d, J = 7.9 Hz, 1H, ArH-4), 7.65 $(\mathrm{t}, J=7.9 \mathrm{~Hz}, 1 \mathrm{H}$, benzyl ArH-4), $7.47(\mathrm{t}, J=6.2 \mathrm{~Hz}, 1 \mathrm{H}$, benzyl ArH-5), $7.24(\mathrm{t}, J=8.4 \mathrm{~Hz}, 1 \mathrm{H}, \mathrm{ArH}-6)$, $7.16(\mathrm{~m}, 1 \mathrm{H}$, benzyl ArH-3), 6.94 (t, J=7.5 Hz, 1H, ArH-5), 6.80 (d, J = 7.5 Hz, 1H, ArH-7), 3.75 (s, $2 \mathrm{H}$, benzyl $\left.\mathrm{CH}_{2}\right), 3.06\left(\mathrm{~m}, 1 \mathrm{H}\right.$, pyrrolidine $\left.\mathrm{H}-2^{\prime}\right), 2.76\left(\mathrm{~d}, J=8.9 \mathrm{~Hz}, 1 \mathrm{H}\right.$, pyrrolidine $\left.\mathrm{H}-5^{\prime}\right), 2.69(\mathrm{~d}, J=8.9 \mathrm{~Hz}$, $1 \mathrm{H}$, pyrrolidine $\left.\mathrm{H}-5^{\prime}\right), 2.61$ (q, $J=7.9 \mathrm{~Hz}, 1 \mathrm{H}$, pyrrolidine $\left.\mathrm{H}-2^{\prime}\right), 2.20-2.15\left(\mathrm{~m}, 1 \mathrm{H}\right.$, pyrrolidine $\left.\mathrm{H}_{-} 4^{\prime}\right)$, 1.92-1.87 (m, 1H, pyrrolidine H-4 $) .{ }^{13} \mathrm{C}-\mathrm{NMR}\left(125 \mathrm{MHz}, \mathrm{DMSO}-d_{6}\right) \delta$ ppm $181.5(\mathrm{C}=\mathrm{O}), 178.0$ (benzyl C-2), 141.6 (C-7a), 137.0 (C-3a), 135.5 (benzyl C-6), 130.2 (benzyl C-4), 127.6 (C-6), 124.7 (benzyl C-1),

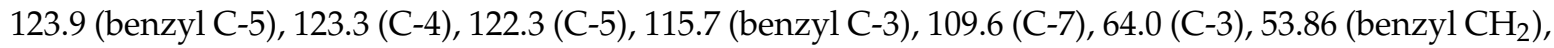
52.9 (pyrrolidine C-2' $), 51.7$ (pyrrolidine C-5'), 37.1 (pyrrolidine C-4'). MS (DUIS+) $m / z 297[\mathrm{M}+\mathrm{H}]^{+}$.

Synthesis of 1'-(2-Fluorobenzyl)-1-(phenylsulfonyl)spiro[indoline-3,3'-pyrrolidine] (44a)

Compound 43a was prepared according to the same procedure as 38a, starting from $42 \mathbf{a}(100 \mathrm{mg}$, $0.3378 \mathrm{mmol})$, using borane-tetrahydrofuran $(0.6757 \mathrm{~mL}, 0.6757 \mathrm{mmol}, 2.5$ equiv.), to afford $10 \mathrm{mg}$ crude product used in the next step without further purification. Compound 44a was prepared according to the same procedure as 39a, starting from crude 43a (10 mg, $0.03545 \mathrm{mmol})$, using benzylsulfonyl chloride (50 mg, $0.07445 \mathrm{mmol}, 1.05$ equiv.), triethylamine $(0.010 \mathrm{~mL}, 0.0709 \mathrm{mmol}$, 2 equiv.) and $N, N$-dimethylpyridin-4-amine $(0.2 \mathrm{mg}, 0.0017 \mathrm{mmol}, 0.5$ equiv. $)$. The product was purified by preparative-HPLC (gradient: water: acetonitrile $0 \%$ to $100 \%$ acetonitrile) Yield: $2 \mathrm{mg}$. ${ }^{1} \mathrm{H}-\mathrm{NMR}\left(500 \mathrm{MHz}_{\mathrm{CDCl}}\right) \delta \mathrm{ppm} 8.22(\mathrm{t}, J=6.7 \mathrm{~Hz}, 2 \mathrm{H}$, phenyl-sulfonyl ArH-3", phenyl-sulfonyl ArH-5"), 7.88 (m, 1H, phenyl-sulfonyl ArH-4"), 7.69 (m, 2H, phenyl-sulfonyl ArH-2", phenyl-sulfonyl ArH-6"), 7.53 (t, J = 6.2 Hz, 1H, benzyl ArH-4), 7.47 (m, 1H, ArH-7), 7.33 (t, J = 7.8 Hz, 1H, benzyl ArH-5), 7.23 (t, $J=7.8$ Hz, 1H, benzyl ArH-6), 7.17-7.08 (m, 2H, ArH-5, ArH-6), 6.73 (d, J = 7.0 Hz, 2H, benzyl ArH-3), 4.22 (m, 2H, H-2), 3.98 (m, 2H, benzyl $\left.\mathrm{CH}_{2}\right), 3.75(\mathrm{~m}, 1 \mathrm{H}$, pyrrolidine H-2') $3.40(\mathrm{~m}, 1 \mathrm{H}$, 
pyrrolidine $\left.\mathrm{H}-2^{\prime}\right), 3.14\left(\mathrm{~m}, 1 \mathrm{H}\right.$, pyrrolidine $\left.\mathrm{H}-5^{\prime}\right), 2.98\left(\mathrm{~m}, 1 \mathrm{H}\right.$, pyrrolidine $\left.\mathrm{H}-5^{\prime}\right), 2.28(\mathrm{~m}, 1 \mathrm{H}$, pyrrolidine $\left.\mathrm{H}-4^{\prime}\right), 1.51$ (m, 1H, pyrrolidine H-4'). ${ }^{13} \mathrm{C}-\mathrm{NMR}\left(125 \mathrm{MHz}, \mathrm{CDCl}_{3}\right) \delta$ ppm 159.3 (benzyl C-2), 144.1 (C-3a), 142.5 (C-7a), 137.3 (phenyl-sulfonyl C-1"), 134.2 (phenyl-sulfonyl C-4"), 130.3 (benzyl C-6), 129.5 (phenyl-sulfonyl C-3", phenyl-sulfonyl C-5"), 129.2 (benzyl C-4), 128.2 (C-6), 127.6 (phenyl-sulfonyl C-2", phenyl-sulfonyl C-6"), 125.8 (benzyl C-1), 125.3 (benzyl C-5), 125.0 (C-4), 121.6 (C-5), 115.7 (benzyl C-3), $113.0(\mathrm{C}-7), 62.3\left(\mathrm{C}-2^{\prime}\right), 59.6\left(\right.$ benzyl $\left.\mathrm{CH}_{2}\right), 55.8(\mathrm{C}-3), 54.9\left(\mathrm{C}-5^{\prime}\right), 53.6(\mathrm{C}-2), 33.1\left(\mathrm{C}-4^{\prime}\right)$. MS (DUIS+) $m / z 423[\mathrm{M}+\mathrm{H}]^{+}$. HRMS (ESI+): $m / z[\mathrm{M}+\mathrm{H}]^{+}$calcd. for $\mathrm{C}_{24} \mathrm{H}_{24} \mathrm{~N}_{2} \mathrm{O}_{2} \mathrm{FS}: 423.1543$; found: 423.1531 .

4.1.8. Procedures to Afford 1'-(3-Fluorobenzyl)-1-(phenylsulfonyl)spiro[indoline-3,3'-pyrrolidine] (44b)

Synthesis of 1'-(3-Fluorobenzyl)spiro[indoline-3,3'-pyrrolidin]-2-one (42b)

To the solution of $41 \mathrm{~b}(1.681 \mathrm{~g}, 6 \mathrm{mmol})$ in tetrahydrofuran: water $(30: 30 \mathrm{~mL})$ was added $30 \mathrm{~mL}$ glacial acetic acid at $0{ }^{\circ} \mathrm{C}$. $\mathrm{N}$-bromosuccinimide $(1.069 \mathrm{~g}, 6 \mathrm{mmol}, 1$ equiv. $)$ was added slowly in portions at $0{ }^{\circ} \mathrm{C}$. The reaction mixture was stirred for $1.5 \mathrm{~h}$ at $0{ }^{\circ} \mathrm{C}$. Afterwards the reaction was quenched at $0{ }^{\circ} \mathrm{C}$ by $40 \mathrm{~mL}$ concentrated sodium-carbonate solution and was stirred for $0.5 \mathrm{~h}$, allowing to warm up to room temperature. The mixture was extracted using ethyl acetate $(2 \times 20 \mathrm{~mL})$. The combined organic phases were washed with concentrated sodium-hydrogen carbonate $(2 \times 20 \mathrm{~mL})$ and by brine $(2 \times 20 \mathrm{~mL})$. The organic phases were dried over sodium-sulfate, filtered and evaporated under reduced pressure. The product $\mathbf{4 2 b}$ was purified by flash chromatography (gradient: dichloromethane: methanol $0 \%$ to $10 \%$ methanol) Yield: $1.31 \mathrm{~g}(76 \%$ calculated to 29$) .{ }^{1} \mathrm{H}-\mathrm{NMR}\left(500 \mathrm{MHz}, \mathrm{DMSO}-d_{6}\right) \delta$ ppm 10.31 (s, 1H, NH), 7.38-7.33 (m, 2H, benzyl H-5, benzyl ArH-6), 7.21-7.16 (m, 3H, ArH-4, benzyl H-2, benzyl ArH-4), 7.04 (m, 1H, ArH-6), 6.98 (t, J = 7.0 Hz, 1H, ArH-5), 6.81 (d, J = 8.0 Hz, 1H, ArH-7), $3.72\left(\mathrm{~s}, 2 \mathrm{H}\right.$, benzyl $\left.\mathrm{CH}_{2}\right), 3.07\left(\mathrm{~m}, 1 \mathrm{H}\right.$, pyrrolidine $\left.\mathrm{H}-2^{\prime}\right), 2.74\left(\mathrm{~d}, J=8.8 \mathrm{~Hz}, 1 \mathrm{H}\right.$, pyrrolidine $\left.\mathrm{H}-5^{\prime}\right)$, $2.66\left(\mathrm{~d}, J=8.8 \mathrm{~Hz}, 1 \mathrm{H}\right.$, pyrrolidine $\left.\mathrm{H}-2^{\prime}\right), 2.56\left(\mathrm{~m}, 1 \mathrm{H}\right.$, pyrrolidine $\left.\mathrm{H}-5^{\prime}\right), 2.20\left(\mathrm{~m}, 1 \mathrm{H}\right.$, pyrrolidine $\left.\mathrm{H}-4^{\prime}\right)$, $1.90\left(\mathrm{~m}, 1 \mathrm{H}\right.$, pyrrolidine $\left.\mathrm{H}-44^{\prime}\right) .{ }^{13} \mathrm{C}-\mathrm{NMR}\left(125 \mathrm{MHz}, \mathrm{CDCl}_{3}\right) \delta \mathrm{ppm} 181.96(\mathrm{C}=\mathrm{O}), 161.2$ (benzyl C-3), 142.3 (C-7a), 141.4 (benzyl C-1), 130.4 (benzyl C-5), 127.8 (benzyl-C6, C-6), 122.1 (benzyl C-2, benzyl C-4), 109.4 (C-7), 64.7 (benzyl $\mathrm{CH}_{2}$ ), 63.9 (C-3), 53.9 (pyrrolidine $\mathrm{C}-2^{\prime}$ ), $52.7\left(\mathrm{C}-5^{\prime}\right), 36.8$ (pyrrolidine C-4'). MS (DUIS+) $m / z 297[\mathrm{M}+\mathrm{H}]^{+}$.

Synthesis of 1'-(3-Fluorobenzyl)-1-(phenylsulfonyl)spiro[indoline-3,3'-pyrrolidine] (44b)

Compound $\mathbf{4 3 b}$ was prepared according to the same procedure as 38a, starting from $\mathbf{4 2 b}$ ( $385 \mathrm{mg}$, $1.3 \mathrm{mmol})$, using borane-tetrahydrofuran $(3.250 \mathrm{~mL}, 3.25 \mathrm{mmolm} 2.5$ equiv.), to afford $338 \mathrm{mg}$ crude product used in the next time without further purification. Compound $44 \mathrm{~b}$ was prepared according to the same procedure as $39 \mathrm{a}$, starting from crude $43 \mathbf{b}(338 \mathrm{mg}, 1.197 \mathrm{mmol})$, using benzylsulfonyl chloride (221 mg, $1.2579 \mathrm{mmol}, 1.05$ equiv.), triethylamine $(0.331 \mathrm{~mL}, 2.396 \mathrm{mmol}, 2$ equiv.) and $\mathrm{N}, \mathrm{N}$-dimethylpyridin-4-amine $(7 \mathrm{mg}, 0.0599 \mathrm{mmol}, 0.5$ equiv.). The product was purified by preparative HPLC (gradient: dichloromethane: methanol $0 \%$ to $10 \%$ methanol) Yield: $11 \mathrm{mg}$. ${ }^{1} \mathrm{H}-\mathrm{NMR}(500 \mathrm{MHz}$, $\left.\mathrm{CDCl}_{3}\right) \delta$ ppm $7.83(\mathrm{~d}, J=8.2 \mathrm{~Hz}, 1 \mathrm{H}, \mathrm{ArH}-7), 7.77(\mathrm{~d}, J=7.6 \mathrm{~Hz}, 1 \mathrm{H}$, benzyl ArH-6), $7.73(\mathrm{~d}, J=7.6$ $\mathrm{Hz}, 1 \mathrm{H}$, ArH-4), 7.64 (d, J = 8.2 Hz, 1H, benzyl ArH-4), 7.58-7.53 (m, 1H, benzyl ArH-5), 7.50-7.39 (m, 3H, phenyl-sulfonyl ArH-3", phenyl-sulfonyl ArH-4", phenyl-sulfonyl ArH-5"), 7.37-7.27 (m, 2H, phenyl-sulfonyl ArH-2", phenyl-sulfonyl ArH-6"), 7.16-7.12 (m, 1H, phenyl-sulfonyl ArH-6), 7.09-7.02 (m, 1H, phenyl-sulfonyl ArH-5), $6.99(\mathrm{~m}, 1 \mathrm{H}$, benzyl H-2), $4.23(\mathrm{~m}, 1 \mathrm{H}, \mathrm{H}-2), 4.11(\mathrm{~m}, 1 \mathrm{H}, \mathrm{H}-2)$, 3.93-3.71 $\left(\mathrm{m}, 2 \mathrm{H}\right.$, benzyl $\left.\mathrm{CH}_{2}\right), 3.23\left(\mathrm{~m}, 1 \mathrm{H}\right.$, pyrrolidine $\left.\mathrm{H}-2^{\prime}\right), 2.94\left(\mathrm{~m}, 1 \mathrm{H}\right.$, pyrrolidine $\left.\mathrm{H}-2^{\prime}\right), 2.83$ $\left(\mathrm{m}, 1 \mathrm{H}\right.$, pyrrolidine $\left.\mathrm{H}-5^{\prime}\right), 2.69\left(\mathrm{~m}, 1 \mathrm{H}\right.$, pyrrolidine $\left.\mathrm{H}-5^{\prime}\right), 2.39-2.25\left(\mathrm{~m}, 1 \mathrm{H}\right.$, pyrrolidine $\left.\mathrm{H}^{\prime} 4^{\prime}\right), 2.18$ (m, 1H, pyrrolidine ${\left.\mathrm{H}-5^{\prime}\right) .}^{13} \mathrm{C}-\mathrm{NMR}\left(125 \mathrm{MHz}, \mathrm{CDCl}_{3}\right) \delta$ ppm 163.0 (benzyl C-3), 143.6 (C-3a), 143.5 (C-7a), 137.6 (phenyl-sulfonyl C-1"), 134.2 (phenyl-sulfonyl C-4"), 130.4 (benzyl C-5), 129.5 (phenyl-sulfonyl C-3", phenyl-sulfonyl C-5"), 129.1 (C-6), 128.0 (phenyl-sulfonyl C-2", phenyl-sulfonyl C-6"), 127.7 (benzyl C-6), 125.6 (benzyl C-1), 125.3 (C-4), 124.1 (C-5), 121.8, 115.8 (benzyl C-2), 113.4 (C-7), 113.3 (benzyl C-4), 61.2 (benzyl $\mathrm{CH}_{2}$ ), 59.9 (pyrrolidine $\mathrm{C}-2^{\prime}$ ), 55.3 (C-3), 54.8 (pyrrolidine $\mathrm{C}-5^{\prime}$ ), 
53.6 (C-2), 33.1 (pyrrolidine C-4'). MS (DUIS+) $m / z 423[\mathrm{M}+\mathrm{H}]^{+}$. HRMS (ESI+): $m / z[\mathrm{M}+\mathrm{H}]^{+}$calcd. for $\mathrm{C}_{24} \mathrm{H}_{24} \mathrm{~N}_{2} \mathrm{O}_{2} \mathrm{SF}$ : 423.1543 ; found: 423.1558 .

4.1.9. Procedures to Afford 1'-(4-Fluorobenzyl)-1-(phenylsulfonyl)spiro[indoline-3,3'-pyrrolidine] (44c)

Synthesis of 1'-(4-Fluorobenzyl)spiro[indoline-3,3'-pyrrolidin]-2-one (42c)

To the solution of $41 \mathrm{c}(2.361 \mathrm{~g}, 8.4321 \mathrm{mmol})$ in tetrahydrofuran: water $(30: 30 \mathrm{~mL})$ was added 30 $\mathrm{mL}$ glacial acetic acid at $0{ }^{\circ} \mathrm{C}$. $\mathrm{N}$-bromosuccinimide $(1.501 \mathrm{~g}, 8.4321 \mathrm{mmol}, 1$ equiv.) was added slowly in portions at $0{ }^{\circ} \mathrm{C}$. The reaction mixture was stirred for $1.5 \mathrm{~h}$ at $0{ }^{\circ} \mathrm{C}$. Afterwards the reaction was quenched at $0{ }^{\circ} \mathrm{C}$ by $40 \mathrm{~mL}$ concentrated sodium-carbonate solution and was stirred for $0.5 \mathrm{~h}$, allowing to warm up to room temperature. The mixture was extracted using ethyl acetate $(2 \times 20 \mathrm{~mL})$. The combined organic phases were washed with concentrated sodium-hydrogen carbonate $(2 \times 20 \mathrm{~mL})$ and by brine $(2 \times 20 \mathrm{~mL})$. The organic phases were dried over sodium-sulfate, filtered and evaporated under reduced pressure. The product $42 \mathrm{c}$ was purified by flash chromatography (gradient: dichloromethane: methanol $0 \%$ to $10 \%$ methanol) Yield: $320 \mathrm{mg}$ (19\% calculated to 25$)$. ${ }^{1} \mathrm{H}-\mathrm{NMR}$ (500 MHz, DMSO- $\left.d_{6}\right) \delta$ ppm $10.30(\mathrm{~s}, 1 \mathrm{H}, \mathrm{NH}), 7.41-7.35$ (m, 3H, benzyl H-2, benzyl ArH-6, ArH-4), $7.16(\mathrm{~m}, 3 \mathrm{H}$, benzyl ArH-3, benzyl ArH-5, ArH-6), $6.96(\mathrm{t}, J=7.2 \mathrm{~Hz}, 1 \mathrm{H}, \mathrm{ArH}-5), 6.81(\mathrm{~d}, J=7.4 \mathrm{~Hz}$, $1 \mathrm{H}, \operatorname{ArH}-7), 5.73\left(\mathrm{~s}, 2 \mathrm{H}\right.$, benzyl $\left.\mathrm{CH}_{2}\right), 3.03\left(\mathrm{~m}, 1 \mathrm{H}\right.$, pyrrolidine $\left.\mathrm{H}-5^{\prime}\right), 2.73(\mathrm{~d}, J=9.3 \mathrm{~Hz}, 1 \mathrm{H}$, pyrrolidine $\left.\mathrm{H}-2^{\prime}\right), 2.64\left(\mathrm{~d}, J=9.3 \mathrm{~Hz}, 1 \mathrm{H}\right.$, pyrrolidine $\left.\mathrm{H}-2^{\prime}\right), 2.58-2.53\left(\mathrm{~m}, 1 \mathrm{H}\right.$, pyrrolidine $\left.\mathrm{H}-5^{\prime}\right), 2.21-2.16(\mathrm{~m}, 1 \mathrm{H}$, pyrrolidine $\left.\mathrm{H}-4^{\prime}\right), 1.95-1.87\left(\mathrm{~m}, 1 \mathrm{H}\right.$, pyrrolidine $\left.\mathrm{H}-4^{\prime}\right){ }^{13} \mathrm{C}-\mathrm{NMR}\left(125 \mathrm{MHz}, \mathrm{DMSO}-d_{6}\right) \delta \mathrm{ppm} 179.1$ (C=O), 161.9 (benzyl C-4), 141.6 (C-7a), 138.2 (benzyl C-1), 134.6 (C-3a), 130.7 (benzyl C-2, benzyl C-6), 128.0 (C-6), 123.3 (C-4), 122.3 (C-2), 115.4 (benzyl C-3, benzyl C-5), 109.6 (C-7), 64.0 (benzyl CH ${ }_{2}$ ), 58.3 (C-3), 54.0 (pyrrolidine C-2'), 52.9 (pyrrolidine C-5'), 37.0 (pyrrolidine C-4'). MS (DUIS+) $m / z 297$ $[\mathrm{M}+\mathrm{H}]^{+}$.

Synthesis of 1'-(4-Fluorobenzyl)-1-(phenylsulfonyl)spiro[indoline-3,3'-pyrrolidine] (44c)

Compound $43 \mathrm{c}$ was prepared according to the same procedure as $38 \mathrm{a}$, starting from $42 \mathrm{c}(310 \mathrm{mg}$, $1.0473 \mathrm{mmol})$, using borane-tetrahydrofuran $(2.620 \mathrm{~mL}, 2.620 \mathrm{mmol}, 2.5$ equiv.), to afford $461 \mathrm{mg}$ crude product used in the next step without further purification. Compound 44c was prepared according to the same procedure as $39 \mathrm{a}$, starting from crude $43 \mathrm{c}(100 \mathrm{mg}, 0.354 \mathrm{mmol})$, using benzylsulfonyl chloride (131 mg, $0.745 \mathrm{mmol}, 1.05$ equiv.), triethylamine $(0.099 \mathrm{~mL}, 0.7092 \mathrm{mmol})$ and $N, N$-dimethylpyridin-4-amine $(2 \mathrm{mg}, 0.01773 \mathrm{mmol})$. The product $44 \mathrm{c}$ was purified by flash chromatography (gradient: dichloromethane: methanol $0 \%$ to $10 \%$ methanol) Yield: $10 \mathrm{mg} .{ }^{1} \mathrm{H}-\mathrm{NMR}$ (500 MHz, CDCl3) $\delta$ ppm 7.84-7.77 (m, 2H, phenyl-sulfonyl ArH-3", phenyl-sulfonyl ArH-5"), 7.74-7.70 (m, 1H, phenyl-sulfonyl ArH-4"), 7.67-7.57 (m, 3H, phenyl-sulfonyl ArH-2", phenyl-sulfonyl ArH-6", ArH-7), 7.50-7.45 (m, 2H, benzyl ArH-2, benzyl ArH-6), 7.43-7.40 (m, 1H, ArH-4), 7.24-7.20 (m, 1H, ArH-6), 7.16-7.12 (m, 2H, benzyl ArH-3, benzyl ArH-5), 7.09 (m, 1H, ArH-5), 4.39 (m, 1H, H-2), 4.29 $(\mathrm{m}, 1 \mathrm{H}, \mathrm{H}-2), 4.18\left(\mathrm{~m}, 1 \mathrm{H}\right.$, benzyl $\left.\mathrm{CH}_{2}\right), 413.06\left(\mathrm{~m}, 1 \mathrm{H}\right.$, benzyl $\left.\mathrm{CH}_{2}\right), 3.90\left(\mathrm{~m}, 1 \mathrm{H}\right.$, pyrrolidine $\left.\mathrm{H}-2^{\prime}\right)$, $3.70\left(\mathrm{~m}, 1 \mathrm{H}\right.$, pyrrolidine $\left.\mathrm{H}-2^{\prime}\right), 3.06(\mathrm{~m}, 1 \mathrm{H}), 2.68\left(\mathrm{~m}, 1 \mathrm{H}\right.$, pyrrolidine $\left.\mathrm{H} 5^{\prime}\right), 2.33(\mathrm{~m}, 1 \mathrm{H}$, pyrrolidine $\left.\mathrm{H}-5^{\prime}\right), 2.33\left(\mathrm{~m}, 1 \mathrm{H}\right.$, pyrrolidine $\left.\mathrm{H}-4^{\prime}\right), 1.75\left(\mathrm{~m}, 1 \mathrm{H}\right.$, pyrrolidine $\left.\mathrm{H}-4^{\prime}\right) .{ }^{13} \mathrm{C}-\mathrm{NMR}\left(125 \mathrm{MHz}, \mathrm{CDCl}_{3}\right) \delta$ ppm 159.8 (benzyl C-4), 144.1 (C-3a), 142.6 (C-7a), 137.5 (benzyl C-1), 134.2 (phenyl-sulfonyl C-1", phenyl-sulfonyl C-4"), 130.7 (benzyl C-2, benzyl C-6), 129.2 (phenyl-sulfonyl C-3", phenyl-sulfonyl C-5"), 128.3 (C-6), 127.7 (phenyl-sulfonyl C-2", phenyl-sulfonyl C-6"), 125.8 (C-4), 125.2 (C-5), 115.5 (benzyl C-3, benzyl C-5), 113.1 (C-7), 62.4 (pyrrolidine C-2'), 59.8 (benzyl $\mathrm{CH}_{2}$ ), 55.5 (C-3), 55.0

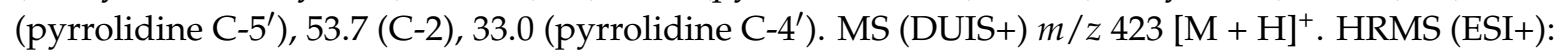
$m / z[\mathrm{M}+\mathrm{H}]^{+}$calcd. for $\mathrm{C}_{24} \mathrm{H}_{24} \mathrm{~N}_{2} \mathrm{O}_{2} \mathrm{SF}: 423.1543$; found: 423.1542 .

\subsubsection{Synthesis of 1'-Benzyl-1-((2-fluorophenyl)sulfonyl)spiro[indoline-3,3'-pyrrolidine] (46a)}

Compound 46a was prepared according to the same procedure as $39 \mathbf{a}$, starting from crude $38 \mathbf{a}$ (15 $\mathrm{mg}, 0.0567 \mathrm{mmol})$, using 2-fluorobenzylsulfonyl chloride (23 mg, $0.11819 \mathrm{mmol})$, triethylamine $(0.015$ 
$\mathrm{mL}, 0.1188 \mathrm{mmol}, 2.1$ equiv.) and $\mathrm{N}, \mathrm{N}$-dimethylpyridin-4-amine ( $0.7 \mathrm{mg}, 0.006 \mathrm{mmol}, 0.1$ equiv.). The product was purified by flash chromatography (gradient: dichloromethane: methanol $0 \%$ to $10 \%$ methanol) Yield: $6.5 \mathrm{mg} .{ }^{1} \mathrm{H}-\mathrm{NMR}\left(500 \mathrm{MHz}, \mathrm{CDCl}_{3}\right) \delta \mathrm{ppm} 8.00(\mathrm{t}, J=6.7 \mathrm{~Hz}, 1 \mathrm{H}$, phenyl-sulfonyl ArH-4"), 7.53 (m, 3H, phenyl-sulfonyl ArH-3", phenyl-sulfonyl ArH-6", ArH-7), 7.41-7.34 (m, 5H, benzyl ArH-2, benzyl ArH-3, benzyl ArH-5, benzyl ArH-6, ArH-4), 7.27 ( $\mathrm{t}, J=$ $8.1 \mathrm{~Hz}, 1 \mathrm{H}$, phenyl-sulfonyl ArH-5"), $7.17(\mathrm{t}, J=8.1 \mathrm{~Hz}, 1 \mathrm{H}$, benzyl ArH-4), $7.10(\mathrm{t}, J=9.4 \mathrm{~Hz}$, $1 \mathrm{H}, \mathrm{ArH}-6), 7.04(\mathrm{t}, J=7.6 \mathrm{~Hz}, 1 \mathrm{H}, \mathrm{ArH}-5), 4.16-4.07\left(\mathrm{~m}, 5 \mathrm{H}\right.$, benzyl $\mathrm{CH}_{2}, \mathrm{H}-2$, pyrrolidine $\left.\mathrm{H}-2^{\prime}\right)$, $3.34\left(\mathrm{~m}, 1 \mathrm{H}\right.$, pyrrolidine $\left.\mathrm{H}-2^{\prime}\right), 3.17\left(\mathrm{~m}, 1 \mathrm{H}\right.$, pyrrolidine $\left.\mathrm{H}-5^{\prime}\right), 3.05\left(\mathrm{~m}, 1 \mathrm{H}\right.$, pyrrolidine $\left.\mathrm{H}-5^{\prime}\right), 2.36$ $\left(\mathrm{m}, 1 \mathrm{H}\right.$, pyrrolidine $\left.\mathrm{H}-4^{\prime}\right), 2.14\left(\mathrm{~m}, 1 \mathrm{H}\right.$, pyrrolidine $\left.\mathrm{H}-4^{\prime}\right) .{ }^{13} \mathrm{C}-\mathrm{NMR}\left(125 \mathrm{MHz}\right.$, DMSO- $\left.d_{6}\right) \delta \mathrm{ppm}$ 155.6 (phenyl-sulfonyl C-2"), 149.7 (C-3a), 142.8 (C-7a), 133.2 (benzyl C-1), 131.8 (phenyl-sulfonyl C-4"), 131.0 (phenyl-sulfonyl C-6"), 129.6 (benzyl C-3, benzyl C-5), 128.4 (benzyl C-2, benzyl C-6), 124.2 (phenyl-sulfonyl C-5"), 122.9 (benzyl C-4), 122.5 (C-4), 121.0 (C-5), 120.4 (phenyl-sulfonyl C-1"), 116.8 (phenyl-sulfonyl C-3"), 111.3 (C-7), 63.2 (pyrrolidine C-2'), 62.6 (benzyl CH $\left.\mathrm{CH}_{2}\right), 55.1$ (C-3), 52.5 (pyrrolidine C-5'), $49.2(\mathrm{C}-2), 37.1$ (pyrrolidine C-4' ${ }^{\prime}$ ). MS (DUIS+) $m / z 423[\mathrm{M}+\mathrm{H}]^{+}$. HRMS (ESI+): $m / z[\mathrm{M}+\mathrm{H}]^{+}$calcd. for $\mathrm{C}_{24} \mathrm{H}_{24} \mathrm{~N}_{2} \mathrm{O}_{2} \mathrm{SF}: 423.1543$; found: 423.1550 .

\subsubsection{Synthesis of 1'-Benzyl-1-((3-fluorophenyl)sulfonyl)spiro[indoline-3,3'-pyrrolidine] (46b)}

Compound $45 \mathbf{b}$ was prepared according to the same procedure as $39 a$, starting from crude $38 \mathbf{a}$ (15 $\mathrm{mg}, 0.0567 \mathrm{mmol})$, using 3-fluorobenzylsulfonyl chloride $(23 \mathrm{mg}, 0.1188 \mathrm{mmol}, 2.1$ equiv.), triethylamine ( $0.015 \mathrm{~mL}, 0.1188 \mathrm{mmol}, 2.1$ equiv.) and $\mathrm{N}, \mathrm{N}$-dimethylpyridin-4-amine $(0.7 \mathrm{mg}, 0.006 \mathrm{mmol}, 0.1$ equiv.). The product was purified by flash chromatography (gradient: dichloromethane: methanol $0 \%$ to $10 \%$ methanol) Yield: $5.5 \mathrm{mg} .{ }^{1} \mathrm{H}-\mathrm{NMR}\left(500 \mathrm{MHz}, \mathrm{CDCl}_{3}\right) \delta$ ppm $8.25(\mathrm{~m}, 1 \mathrm{H}$, phenyl-sulfonyl ArH-2"), 7.65-7.58 (m, 2H, phenyl-sulfonyl ArH-5", phenyl-sulfonyl ArH-6"), 7.48-7.38 (m, 6H, ArH-7, benzyl ArH-2-6), 7.29-7.25 (m, 2H, ArH-4, ArH-6), 7.21 (m, 1H, phenyl-sulfonyl ArH-4"), 7.08 (t, J = 7.6 Hz, $1 \mathrm{H}$, ArH-5), $\left.4.16(\mathrm{~d}, J=12.7 \mathrm{~Hz}, 1 \mathrm{H} \text {, benzyl CH})_{2}, 4.09(\mathrm{~d}, J=12.7 \mathrm{~Hz}, 1 \mathrm{H} \text {, benzyl CH})_{2}\right), 3.99(\mathrm{~d}, J=10.9$ $\mathrm{Hz}, 1 \mathrm{H}, \mathrm{H}-2), 3.85$ (d, $J=10.9 \mathrm{~Hz}, 1 \mathrm{H}, \mathrm{H}-2), 3.33-3.24\left(\mathrm{~m}, 2 \mathrm{H}\right.$, pyrrolidine $\left.\mathrm{H}-2^{\prime}\right), 3.12(\mathrm{~d}, J=11.6 \mathrm{~Hz}$, $1 \mathrm{H}$, pyrrolidine $\left.\mathrm{H}-5^{\prime}\right), 3.00\left(\mathrm{~d}, J=11.6 \mathrm{~Hz}, 1 \mathrm{H}\right.$, pyrrolidine $\left.\mathrm{H}-5^{\prime}\right), 2.26-2.20\left(\mathrm{~m}, 1 \mathrm{H}\right.$, pyrrolidine $\left.\mathrm{H}-4^{\prime}\right)$, 2.05-2.00 (m, $1 \mathrm{H}$, pyrrolidine $\left.\mathrm{H}-4^{\prime}\right) .{ }^{13} \mathrm{C}-\mathrm{NMR}\left(125 \mathrm{MHz}, \mathrm{CDCl}_{3}\right) \delta \mathrm{ppm} 158.6$ (phenyl-sulfonyl C-3"), 146.8 (C-3a), 145.4 (C-7a), 137.5 (benzyl C-1), 130.5 (phenyl-sulfonyl C-1"), 129.7 (phenyl-sulfonyl C-5"), 129.0 (benzyl C-3, benzyl C-5), 128.7 (benzyl C-2, benzyl C-6), 124.5 (C-6), 122.8 (benzyl C-4), 122.7 (phenyl-sulfonyl C-6"), 121.7 (C-4), 120.2 (C-5), 117.7 (phenyl-sulfonyl C-4"), 114.3 (phenyl-sulfonyl C-2"), 109.5 (C-7), 63.0 (pyrrolidine C-2'), 62.6 (benzyl $\mathrm{CH}_{2}$ ), $55.4(\mathrm{C}-3), 52.7$ (pyrrolidine $\left.\mathrm{C}-5^{\prime}\right), 49.2$ (C-2), 37.9 (pyrrolidine C-4'). MS (DUIS+) $m / z 423[\mathrm{M}+\mathrm{H}]^{+}$. HRMS (ESI+): $m / z[\mathrm{M}+\mathrm{H}]^{+}$calcd. for $\mathrm{C}_{24} \mathrm{H}_{24} \mathrm{~N}_{2} \mathrm{O}_{2}$ SF: 423.1543 ; found: 423.1547.

\subsubsection{Synthesis of 1'-Benzyl-1-((4-fluorophenyl)sulfonyl)spiro[indoline-3,3'-pyrrolidine] (46c)}

Compound 46c was prepared according to the same procedure as 39a, starting from crude 38a (15 mg, $0.0567 \mathrm{mmol}$ ), using 4-fluorobenzylsulfonyl chloride ( $23 \mathrm{mg}, 0.1182 \mathrm{mmol}, 2.1$ equiv.), triethylamine $(0.015 \mathrm{~mL}, 0.1188 \mathrm{mmol}, 2.1$ equiv. $)$ and $N, N$-dimethylpyridin-4-amine $(0.7 \mathrm{mg}$, $0.006 \mathrm{mmol}, 0.1$ equiv.). The product was purified by flash chromatography (gradient: dichloromethane: methanol $0 \%$ to $10 \%$ methanol) Yield: $7.7 \mathrm{mg} .{ }^{1} \mathrm{H}-\mathrm{NMR}\left(500 \mathrm{MHz}, \mathrm{CDCl}_{3}\right) \delta \mathrm{ppm} 7.80(\mathrm{~m}, 2 \mathrm{H}$, phenyl-sulfonyl ArH-3", phenyl-sulfonyl ArH-5"), 7.63 (d, J = 7.9 Hz, 1H, ArH-7), 7.47 (m, 2H, benzyl H-3, benzyl ArH-5), 7.40 (m, 3H, benzyl ArH-2, benzyl ArH-4, benzyl ArH-6), 7.28 (m, 2H, phenyl-sulfonyl ArH-3", phenyl-sulfonyl ArH-5"), 7.09-7.05 (m, 3H, ArH-4, ArH-5, ArH-6), 4.10 (d, $J=12.3 \mathrm{~Hz}, 1 \mathrm{H}, \mathrm{H}-2), 4.02-3.96\left(\mathrm{~m}, 2 \mathrm{H}\right.$, benzyl $\left.\mathrm{CH}_{2}\right), 3.84(\mathrm{~d}, J=11.3 \mathrm{~Hz}, 1 \mathrm{H}, \mathrm{H}-2), 3.25(\mathrm{~m}, 1 \mathrm{H}$, pyrrolidine $\left.\mathrm{H}_{-} 2^{\prime}\right), 3.16\left(\mathrm{~m}, 1 \mathrm{H}\right.$, pyrrolidine $\left.\mathrm{H}-2^{\prime}\right), 2.94\left(\mathrm{~m}, 1 \mathrm{H}\right.$, pyrrolidine $\left.\mathrm{H}-5^{\prime}\right), 2.89(\mathrm{~m}, 1 \mathrm{H}$, pyrrolidine

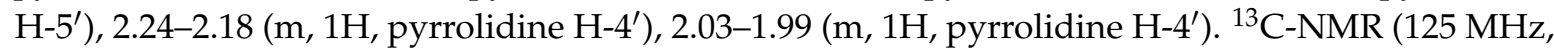
$\mathrm{CDCl}_{3}$ ) $\delta$ ppm 163.7 (phenyl-sulfonyl C-4"), 152.7 (C-3a), 150.6 (C-7a), 147.0 (benzyl C-1), 129.6 (phenyl-sulfonyl C-1"), 129.5 (phenyl-sulfonyl C-2", phenyl-sulfonyl C-6"), 129.2 (benzyl C-3, benzyl C-5), 129.1 (benzyl C-2, benzyl C-6), 128.8 (C-6), 128.6 (benzyl C-4), 125.6 (C-4), 124.4 (C-5), 122.8 
(phenyl-sulfonyl C-3", phenyl-sulfonyl C-5"), 116.1 (C-7), 63.1 (pyrrolidine C-2'), 62.4 (benzyl $\mathrm{CH}_{2}$ ), 54.1 (C-3), 52.8 (pyrrolidine C-5'), 49.1 (pyrrolidine C-2'), 36.6 (pyrrolidine C-4'). MS (DUIS+) $m / z 423$ $[\mathrm{M}+\mathrm{H}]^{+}$. HRMS (ESI+): $m / z$ [M + H] ${ }^{+}$calcd. for $\mathrm{C}_{24} \mathrm{H}_{24} \mathrm{~N}_{2} \mathrm{O}_{2}$ SF: 423.1543; found: 423.1563 .

\subsection{General Procedure for the Serotonergic Screening Assays}

\subsubsection{Cell Culture and Preparation of Cell Membranes}

HEK293 cells with stable expression of human serotonin $5-\mathrm{HT}_{1 \mathrm{~A}}, 5-\mathrm{HT}_{6}$ or $5-\mathrm{HT}_{7 \mathrm{~b}}$ receptors (all prepared with the use of Lipofectamine 2000) or CHO-K1 cells with plasmid containing the sequence coding for the human serotonin $5-\mathrm{HT}_{2 \mathrm{~A}}$ receptor (PerkinElmer) were maintained at $37^{\circ} \mathrm{C}$ in a humidified atmosphere with $5 \% \mathrm{CO}_{2}$ and were grown in Dulbeco's Modifier Eagle Medium containing $10 \%$ dialysed fetal bovine serum and $500 \mu \mathrm{g} / \mathrm{mL}$ G418 sulphate. For membranes preparations, cells were subcultured in $150 \mathrm{~cm}^{2}$ flasks, grown to $90 \%$ confluence, washed twice with prewarmed to $37^{\circ} \mathrm{C}$ phosphate buffered saline (PBS) and were pelleted by centrifugation ( $200 \mathrm{~g})$ in PBS containing $0.1 \mathrm{mM}$ EDTA and $1 \mathrm{mM}$ dithiothreitol. Prior to membrane preparations pellets were stored at $-80^{\circ} \mathrm{C}$.

\subsubsection{Radioligand Binding Assays}

Cell pellets were thawed and homogenized in 10 volumes of assay buffer using an Ultra Turrax tissue homogenizer and centrifuged twice at $35,000 \mathrm{~g}$ for $20 \mathrm{~min}$ at $4{ }^{\circ} \mathrm{C}$, with incubation for $15 \mathrm{~min}$ at $37^{\circ} \mathrm{C}$ in between. The composition of the assay buffers was as follows: for $5-\mathrm{HT}_{1 \mathrm{~A}} \mathrm{R}: 50 \mathrm{mM}$ Tris- $\mathrm{HCl}$, $0.1 \mathrm{mM}$ EDTA, $4 \mathrm{mM} \mathrm{MgCl} 2,10 \mu \mathrm{M}$ pargyline and $0.1 \%$ ascorbate; for 5- $\mathrm{HT}_{2 \mathrm{~A}} \mathrm{R}: 50 \mathrm{mM}$ Tris- $\mathrm{HCl}, 0.1$ mM EDTA, $4 \mathrm{mM} \mathrm{MgCl}_{2}$ and $0.1 \%$ ascorbate; for 5- $\mathrm{HT}_{6} \mathrm{R}: 50 \mathrm{mM}$ Tris-HCl, $0.5 \mathrm{mM}$ EDTA and $4 \mathrm{mM}$ $\mathrm{MgCl}_{2}$, for $5-\mathrm{HT}_{7 \mathrm{~b}} \mathrm{R}: 50 \mathrm{mM}$ Tris- $\mathrm{HCl}, 4 \mathrm{mM} \mathrm{MgCl} 2,10 \mu \mathrm{M}$ pargyline and $0.1 \%$ ascorbate. All assays were incubated in a total volume of $200 \mu \mathrm{L}$ in 96-well microtiter plates for $1 \mathrm{~h}$ at $37^{\circ} \mathrm{C}$, except for $5-\mathrm{HT}_{1 \mathrm{~A}} \mathrm{R}$ and $5-\mathrm{HT}_{2 \mathrm{~A}} \mathrm{R}$ which were incubated at room temperature for $1 \mathrm{~h}$ and $1.5 \mathrm{~h}$ respectively. The process of equilibration is terminated by rapid filtration through Unifilter plates with a 96-well cell harvester and radioactivity retained on the filters was quantified on a Microbeta plate reader (PerkinElmer).

For displacement studies the assay samples contained as radioligands: $2.5 \mathrm{nM}\left[{ }^{3} \mathrm{H}\right]-8-\mathrm{OH}-\mathrm{DPAT}$ (5002.4 GBq/mmol) for $5-\mathrm{HT}_{1 \mathrm{~A}} \mathrm{R} ; 1 \mathrm{nM}\left[{ }^{3} \mathrm{H}\right]-$ Ketanserin $(1975.8 \mathrm{GBq} / \mathrm{mmol})$ for $5-\mathrm{HT}_{2 \mathrm{~A}} \mathrm{R} ; 2 \mathrm{nM}$ $\left[{ }^{3} \mathrm{H}\right]-\mathrm{LSD}(3093.2 \mathrm{GBq} / \mathrm{mmol})$ for $5-\mathrm{HT}_{6} \mathrm{R}$ or $0.8 \mathrm{nM}\left[{ }^{3} \mathrm{H}\right]-5-\mathrm{CT}(1450.4 \mathrm{GBq} / \mathrm{mmol})$ for $5-\mathrm{HT}_{7} \mathrm{R}$. Non-specific binding is defined with $10 \mu \mathrm{M}$ of $5-\mathrm{HT}$ in $5-\mathrm{HT}_{1 \mathrm{~A}} \mathrm{R}$ and $5-\mathrm{HT}_{7} \mathrm{R}$ binding experiments, whereas $10 \mu \mathrm{M}$ of chlorpromazine or $10 \mu \mathrm{M}$ of methiothepine were used in $5-\mathrm{HT}_{2 \mathrm{~A}} \mathrm{R}$ and $5-\mathrm{HT}_{6} \mathrm{R}$ assays, respectively. Each compound was tested in triplicate at $7-8$ concentrations $\left(10^{-11}-10^{-4} \mathrm{M}\right)$. The inhibition constants $\left(K_{\mathrm{i}}\right)$ were calculated from the Cheng-Prusoff equation [47]. Results were expressed as means of at least three separate experiments (SD $\leq 24 \%$ ).

\subsubsection{Docking Procedure}

The homology model of h-5 $\mathrm{HT}_{6} \mathrm{R}$ [15] was prepared for docking experiment my Schrödinger's Protein Preparation Wizard by default settings for protomer-state optimization and restrained minimization by OPLS_2005 force field. Single precision docking was performed with Schrödinger's Glide by default settings. The ligand (46a) was prepared for docking by Schrödinger's LigPrep, generating possible ionization states (at $\mathrm{pH}$ range of $7.0 \pm 2.0$ ), tautomers and stereoisomers. Constrained docking was set to two required interactions (at least 1 match): hydrogen bond formed with Asn $288^{6.55}$ and/or hydrogen bond formed with Ser193 $3^{5.43}$.

Acknowledgments: The authors are grateful to László Drahos and Ágnes Gömöry (RCNS, Hungary) for the exact mass (high-resolution MS) measurements and we are thankful for Aaron Keeley (RCNS, Hungary) for carefully reading the manuscript and for Stefan Mordalski (Institute of Pharmacology, Poland) for helpful discussions. The support of the National Brain Research Program (KTIA_NAP_13-1-2013-0001) is acknowledged. 
Author Contributions: G.M.K. and A.J.B. conceived the study; Á.A.K. performed the syntheses, G.S. performed the in vitro measurements.

Conflicts of Interest: The authors declare no conflict of interest.

\section{References}

1. Russel, J.S. Oxindoles and spirocyclic variations: Strategies for C3 functionalization. Top. Heterocycl. Chem. 2011, 26, 397-432. [CrossRef]

2. Bindra, J.S. Oxindole alkaloids. Alkaloids Chem. Physiol. 1973, 14, 83-121. [CrossRef]

3. ChEMBL. Available online: Https://www.ebi.ac.uk/chembl/ (accessed on 12 October 2017).

4. Kelemen, Á.A.; Ferenczy, G.G.; Keseru, G.M. A desirability function-based scoring scheme for selecting fragment-like class A aminergic GPCR ligands. J. Comput. Aided Mol. Des. 2015, 29, 59-66. [CrossRef] [PubMed]

5. Kelemen, Á.A.; Kiss, R.; Ferenczy, G.G.; Kovács, L.; Flachner, B.; Lorincz, Z.; Keseru, G.M. Structure-based consensus scoring scheme for selecting class A aminergic GPCR fragments. J. Chem. Inf. Model. 2016, 56, 412-422. [CrossRef] [PubMed]

6. Upton, N.; Chuang, T.T.; Hunter, A.J.; Virley, D.J. 5-HT 6 receptor antagonists as novel cognitive enhancing agents for Alzheimer's disease. Neurotherapeutics 2008, 5, 458-469. [CrossRef] [PubMed]

7. Messina, D.; Annesi, G.; Serra, P.; Nicoletti, G.; Pasqua, A.; Annesi, F.; Tomaino, C.; Cirò-Candiano, I.C.; Carrideo, S.; Caracciolo, M.; et al. Association of the 5- $\mathrm{HT}_{6}$ receptor gene polymorphism C267T with Parkinson's disease. Neurology 2002, 58, 828-829. [CrossRef] [PubMed]

8. Codony, X.; Vela, J.M.; Ramírez, M.J. 5-HT 6 receptor and cognition. Curr. Opin. Pharmacol. 2011, 11, $94-100$. [CrossRef] [PubMed]

9. Holenz, J.; Mercè, R.; Díaz, J.L.; Guitart, X.; Codony, X.; Dordal, A.; Romero, G.; Torrens, A.; Mas, J.; Andaluz, B.; et al. Medicinal chemistry driven approaches toward novel and selective serotonin 5- $\mathrm{HT}_{6}$ receptor ligands. J. Med. Chem. 2005, 48, 1781-1795. [CrossRef] [PubMed]

10. Kobilka, B.K. G protein coupled receptor structure and activation. Biochim. Biophys. Acta Biomembr. 2007, 1768, 794-807. [CrossRef] [PubMed]

11. Ivachtchenko, A.V. Sulfonyl-containing modulators of serotonin 5- $\mathrm{HT}_{6}$ receptors and their pharmacophore models. Russ. Chem. Rev. 2014, 83, 439-473. [CrossRef]

12. Staroń, J.; Warszycki, D.; Kalinowska-Tłuścik, J.; Satała, G.; Bojarski, A.J. Rational design of 5-HT 6 R ligands using a bioisosteric strategy: Synthesis, biological evaluation and molecular modelling. RSC Adv. 2015, 5, 25806-25815. [CrossRef]

13. Mcule. Available online: https:/ / mcule.com/ (accessed on 12 October 2017).

14. Small-Molecule Drug Discovery Suite 2017-3; Schrödinger, LLC: New York, NY, USA, 2017.

15. Vass, M.; Jójárt, B.; Bogár, F.; Paragi, G.; Keseru, G.M.; Tarcsay, Á. Dynamics and structural determinants of ligand recognition of the 5- $\mathrm{HT}_{6}$ receptor. J. Comput. Aided Mol. Des. 2015, 29, 1137-1149. [CrossRef] [PubMed]

16. Wacker, D.; Wang, C.; Katritch, V.; Han, G.W.; Huang, X.-P.; Vardy, E.; McCorvy, J.D.; Jiang, Y.; Chu, M.; Siu, F.Y.; et al. Structural features for functional selectivity at serotonin receptors. Science 2013, 340, 615-619. [CrossRef] [PubMed]

17. Kelemen, Á.A.; Mordalski, S.; Bojarski, A.J.; Keserú, G.M. Computational modeling of drugs for Alzheimer's disease: Design of serotonin 5-HT 6 antagonists. In Computational Modeling of Drugs against Alzheimer's Disease; Humana Press: New York, NY, USA, 2017; Volume 132, pp. 419-461. ISBN 978-1-4939-7403-0.

18. Laronze, J.-Y.; Bascop, S.I.; Sápi, J.; Levy, J. On the synthesis of the oxindole alkaloid: $( \pm)$-Horsfiline. Heterocycles 1994, 38. [CrossRef]

19. Overman, L.E.; Rosen, M.D. Total synthesis of (-)-spirotryprostatin B and three stereoisomers. Angew. Chem. Int. Ed. 2000, 39, 4596-4599. [CrossRef]

20. Finch, N.; Taylor, W.I. The conversion of tetrahydro- $\beta$-carboline alkaloids into oxindoles. The structures and partial syntheses of mitraphylline and rhyn cophylline. J. Am. Chem. Soc. 1962, 84, 1318-1320. [CrossRef]

21. Wang, H.; Ganesan, A. A biomimetic total synthesis of (-)-spirotryprostatin B and related studies. J. Org. Chem. 2000, 65, 4685-4693. [CrossRef] [PubMed] 
22. Sebahar, P.R.; Williams, R.M. The asymmetric total synthesis of (+)- and (-)-spirotryprostatin B. J. Am. Chem. Soc. 2000, 122, 5666-5667. [CrossRef]

23. Jones, K.; Wilkinson, J. A total synthesis of horsfiline via aryl radical cyclisation. J. Chem. Soc. Chem. Commun. 1992, 5, 1767-1769. [CrossRef]

24. Abelman, M.M.; Oh, T.; Overman, L.E. Intramolecular alkene arylations for rapid assembly of polycyclic systems containing quaternary centers. A new synthesis of spirooxindoles and other fused and bridged ring systems. J. Org. Chem. 1987, 52, 4130-4133. [CrossRef]

25. Fuji, K.; Node, M.; Nagasawa, H.; Naniwa, Y.; Terada, S. Asymmetric Induction via addition-elimination process: Nitroolefination of $\alpha$-substituted lactones. J. Am. Chem. Soc. 1986, 108, 3855-3856. [CrossRef]

26. Stahl, R.; Borschberg, H.-J. A Reinvestigation of the oxidative rearrangement of yohimbane-type alkaloids. Part A. Formation of pseudoindoxyl (=1,2-dihydro-3H-indol-3-one) derivatives. Helv. Chim. Acta 1994, 77, 1331-1345. [CrossRef]

27. Shavel, J.; Zinnes, H.; Oxindole Alkaloids, I. Oxidative-rearrangement of indole alkaloids to their oxindole analogs. J. Am. Chem. Soc. 1962, 84, 1320-1321. [CrossRef]

28. Martin, S.F.; Mortimore, M. New methods for the synthesis of oxindole alkaloids. Total syntheses of isopteropodine and pteropodine. Tetrahedron Lett. 1990, 31, 4557-4560. [CrossRef]

29. Takayama, H.; Seki, N.; Kitajima, M.; Aimi, N.; Seki, H.; Sakai, S.-I. Indoloquinolizidine and yohimbine were converted to the corresponding Na-methoxyindoles and Na-methoxyoxindoles by the oxidation of the dihydroindole derivatives with $\mathrm{H}_{2} \mathrm{O}_{2}$ and sodium tungstate. Heterocycles 1992, 33, 121-125. [CrossRef]

30. Yu, P.; Cook, J.M. Diastereospecific synthesis of ketooxindoles. Potential intermediates for the synthesis of alstonisine as well as for voachalotine related oxindole alkaloids. Tetrahedron Lett. 1997, 38, 8799-8802. [CrossRef]

31. Pellegrini, C.; Strässler, C.; Weber, M.; Borschberg, H.J. Synthesis of the oxindole alkaloid (-)-horsfiline. Tetrahedron Asymmetry 1994, 5, 1979-1992. [CrossRef]

32. Edmondson, S.D.; Danishefsky, S.J. The total synthesis of spirotryprostatin A. Angew. Chem. Int. Ed. 1998, 37, 1138-1140. [CrossRef]

33. Edmondson, S.; Danishefsky, S.J.; Sepp-Lorenzino, L.; Rosen, N. Total synthesis of spirotryprostatin A, leading to the discovery of some biologically promising analogues. J. Am. Chem. Soc. 1999, 121, 2147-2155. [CrossRef]

34. Pictet, A.; Spengler, T. Über die Bildung von Isochinolin Derivaten durch Einwirkung von Methylal auf Phenylethylamin, Phenylalanin und Tyrosin. Eur. J. Inorg. Chem. 1911, 44, 2030-2036. [CrossRef]

35. Zhao, Y.; Yu, S.; Sun, W.; Liu, L.; Lu, J.; McEachern, D.; Shargary, S.; Bernard, D.; Li, X.; Zhao, T.; et al. A potent small-molecule inhibitor of the MDM2-p53 interaction (MI-888) achieved complete and durable tumor regression in mice. J. Med. Chem. 2013, 56, 5553-5561. [CrossRef] [PubMed]

36. Kath, J.C.; Tom, N.J.; Cox, E.D.; Bhattacharya, S.K. Heteroaromatic Bicyclic Derivatives Useful as Anticancer Agents. U.S. Patent 6,867,201 B2, 22 August 2002.

37. Powell, N.A.; Kohrt, J.T.; Filipski, K.J.; Kaufman, M.; Sheehan, D.; Edmunds, J.E.; Delaney, A.; Wang, Y.; Bourbonais, F.; Lee, D.Y.; et al. Novel and selective spiroindoline-based inhibitors of sky kinase. Bioorg. Med. Chem. Lett. 2012, 22, 190-193. [CrossRef] [PubMed]

38. Li, C.; Chan, C.; Heimann, A.C.; Danishefsky, S.J. On the rearrangement of an azaspiroindolenine to a precursor to phalarine: Mechanistic insights. Angew. Chem. Int. Ed. 2007, 46, 1444-1447. [CrossRef] [PubMed]

39. Ottoni, O.; Cruz, R.; Krammer, N.H. Regioselective nitration of 3-acetylindole and its N-acyl and N-sulfonyl derivatives. Tetrahedron Lett. 1999, 40, 1117-1120. [CrossRef]

40. Lakshmaiah, G.; Kawabata, T.; Shang, M.; Fuji, K. Total synthesis of (-)-horsfiline via asymmetric nitroolefination. J. Org. Chem. 1999, 64, 1699-1704. [CrossRef] [PubMed]

41. Aurora Fine Chemicals Inc. Available online: http://www.aurorafinechemicals.com/ (accessed on 22 April 2017).

42. Mitchell, I.S.; Blake, J.F.; Xu, R.; Kallan, N.C.; Xiao, D.; Spencer, K.L.; Bencsik, J.R.; Liang, J.; Safina, B.; Zhang, B.; et al. Hydroxylated and Methoxylated Cyclopenta [D] Pyrimidines as Akt Protein Kinase Inhibitors. Patent No. CA26,56,622 A1, 5 July 2007.

43. Hostetler, G.; Dunn, D.; McKenna, B.A.; Kopec, K.; Chatterjee, S. 1-Thia-4,7-diaza-spiro[4.4]nonane-3,6-dione: A structural motif for 5-hydroxytryptamine 6 receptor antagonism. Chem. Biol. Drug Des. 2014, 83, 149-153. [CrossRef] [PubMed] 
44. Protiva, M.; Vejdělek, Z.J.; Jílek, J.O.; Macek, K. Synthetische modelle hypotensiv wirksamer alkaloide V. Einige weitere derivate des tryptamins und 1,2,3,4-tetrahydronorharmans. Collect. Czechoslov. Chem. Commun. 1959, 24, 3978-3987. [CrossRef]

45. Bell, S.E.V.; Brown, R.F.C.; Eastwood, F.W.; Horvath, J.M. An approach to some spiro oxindole alkaloids through cycloaddition reactions of 3-methylideneindolin-2-one. Aust. J. Chem. 2000, 53. [CrossRef]

46. Lim, Y.-H.; Guo, Z.; Ali, A.; Edmondson, S.D.; Liu, W.; Gallo-Ettienne, G.V.; Wu, H.; Gao, Y.-D.; Stamford, A.M.; Yu, Y.; et al. Factor XIa Inhibitors. Patent No. WO201,5164,308, 29 October 2015.

47. Allen, J.; Brasseur, D.M.; De Bruin, B.; Denoux, M.; Pérard, S.; Philippe, N.; Roy, S.N. The use of biocatalysis in the synthesis of labelled compounds. J. Label. Compd. Radiopharm. 2007, 50, 342-346. [CrossRef]

48. Manda, S.; Khan, S.I.; Jain, S.K.; Mohammed, S.; Tekwani, B.L.; Khan, I.A.; Vishwakarma, R.A.; Bharate, S.B. Synthesis, antileishmanial and antitrypanosomal activities of $\mathrm{N}$-substituted tetrahydro- $\beta$-carbolines. Bioorg. Med. Chem. Lett. 2014, 24, 3247-3250. [CrossRef] [PubMed]

49. Sevrin, M.; Morel, C.; Menin, J.; George, P. 2-(Methyl(4-piperidinyl))-1,2,3,4-tetrahydro-9H-pyrido(3,4-b Indole Derivatives, Their Preparation and Therapeutical Use. Patent No. EP0,302,788 B1, 5 February 1992.

50. Shah, P.; Westwell, A.D. The role of fluorine in medicinal chemistry. J. Enzym. Inhib. Med. Chem. 2007, 22, 527-540. [CrossRef] [PubMed]

Sample Availability: Samples of the compounds are not available from the authors.

(C) 2017 by the authors. Licensee MDPI, Basel, Switzerland. This article is an open access article distributed under the terms and conditions of the Creative Commons Attribution (CC BY) license (http:/ / creativecommons.org/licenses/by/4.0/). 